\title{
RDUS
}

Revue de DROIT UNIVERSITÉ DE SHERBROOKE

Titre : $\quad$ IMPLICIT COMPARATIVE LAW

Auteur(s): $\quad$ Roderick A. MACDONALD

Kate GLOVER

Revue : $\quad$ RDUS, 2013, volume 43, numéro 1-2

Pages: $\quad$ 123-192

ISSN : $\quad$ 0317-9656

Éditeur: Université de Sherbrooke. Faculté de droit.

URI : $\quad$ http://hdl.handle.net/11143/10194

DOI : https://doi.org/10.17118/11143/10194 
Page vide laissée intentionnellement. 


\title{
ARTICLE
}

\section{IMPLICIT COMPARATIVE LAW}

\author{
par Roderick A. MACDONALD ${ }^{* \star}$ \\ Kate GLOVER ${ }^{* * *}$
}

La littérature contemporaine en droit comparé est tributaire, tant dans ses aspects méthodologique que théorique, de réflexions méticuleuses et fouillées cherchant à identifier l'essence, les objectifs et les limites de la discipline. Malgré les contributions créatives de ces démarches, la plupart des analyses demeurent attachées aux conceptions du droit définies par les frontières traditionnelles, que celles-ci soient officielles, explicites ou externes. Cet article s'attarde plutôt à imaginer le droit comparé débarrassé de ses liens avec le positivisme étatique, lui préférant une approche fondée sur le pluralisme juridique. Dans cette perspective, les individus plutôt que les agents des systèmes officiels sont les acteurs au coeur du juridique (et du comparé). De plus, cette approche ne présume pas la supériorité des formes explicites de normativité, reconnaissant autant d'influence aux éléments implicites inhérents à tout ordre juridique. Finalement, elle valorise les comparaisons en jeu dans les actes quotidiens et les interactions de tous les jours entre les individus. Ultimement, l'article offre une réponse à la question: les comparaisons de qui, de quel droit, selon quels axes, par quelle méthode, dans quel but?

Contemporary comparative law scholarship has been enriched, methodologically and theoretically, by careful, searching accounts of the essence, aims and limits of the comparative legal endeavour. Yet, despite creative contributions to the field, most scholarly analyses remain tethered to conceptions of law demarcated by traditional boundaries - the official, the explicit and the external. In this paper, we contemplate what comparative law would look like if its practitioners abandoned their attachment to state legal positivism and adopted instead an approach grounded in a pluralist hypothesis of law. The alternative that we envision, which posits individuals rather than agents of official systems as the central legal (and comparative) actors. Moreover, it does not privilege explicit forms of normativity over the equally influential tacit forms that are inherent in all legal orders. Finally, this approach values the comparisons at stake in the everyday actions and interactions of individuals. Ultimately, we offer a response to the question: Whose comparisons, of what law, along which axes, by what method, to what end?

* . This is a revised version of a presentation given at the 50th Anniversary Conference of the Québec Society of Comparative Law held at the Faculté de droit de l'Université de Sherbrooke on October 28-29, 2011. The authors are grateful to the conference participants for their thoughtful comments on an earlier version of this paper and to Patrick Glenn for his insight into the authoritative texts of comparative law. We would also like to thank Hoi Kong, Tom McMorrow, Robert Leckey, Alexandra Popovici and Lionel Smith who read and critiqued the penultimate version. Finally, we are grateful to the two anonymous reviewers whose questions have enabled us to clarify certain arguments in parts of the text that they found underdeveloped. All errors and inconsistencies remain our own.

** . F.R. Scott Professor of Constitutional and Public Law, McGill University; F.R.S.C.

*** . D.C.L. Candidate, McGill University; Vanier Canada Graduate Scholar (2012-2015); O’Brien Fellow for Human Rights and Legal Pluralism (20102012). 


\section{TABLE OF CONTENTS}

I. Introduction 125

II. Implicit Comparative Law: A Syllabus ................... 129

A. Synopsis and Rationale ............................. 129

B. Course Objectives ..................................... 140

C. Specific Learning Outcomes ......................... 150

D. Primary Reference Materials .......................... 156

E. Course Content and Pedagogical Approach......... 162

F. Assignments and Assessment ....................... 169

G. Feedback ........................................ 175

H. Week-by-Week Outline of Seminar Sessions ........ 179

III. Conclusion f.............................................. 180

Appendix: Annotated Bibliography ........................... 184 


\section{INTRODUCTION}

This paper re-imagines the meta-framework and objects of comparative law. ${ }^{1}$ Like traditional approaches to comparative law, the framework we propose celebrates comparison as a rich and instructive source of legal knowledge. Like more modern, but nonetheless orthodox, approaches, our framework is fundamentally concerned not just with the identification and comparison of norms, concepts and institutions, but also with what law and society scholars call internormativity - the interaction and movement of these norms, concepts and institutions between legal orders. Yet, unlike both traditional and modern conceptions of comparative law, we do not structure the comparative endeavour by reference only to political units (states); nor do we limit our inventory of comparative objects to official legal artefacts such as statutes and judicial decisions or to exegetical doctrinal understandings of these artefacts. Rather, the organizing meta-framework of the alternative we offer sees normative plurality and the challenge of comparison in the everyday actions of individual legal agents. We conceive each legal agent, inappropriately reduced to a passive "norm subject" in traditional analysis, as the mediator of identity and difference among the multiple legal orders in which she or he is situated. This alternative, agent-centred meta-framework is the foundation of what we call implicit comparative law.

The hypotheses and methods of implicit comparative law are relatively easy to formulate in the abstract. But, since we believe that a particularly powerful mechanism for learning, interpreting and assessing a body of knowledge and for perfecting a methodology appropriate to the task is to attempt their teaching, we decided to

1. In view of the manner in which we have chosen to present this reimagination, for the most part we forego point-by-point footnoting for the ideas and themes raised in the text. The section entitled "Primary Reference Materials" (II.D) and the Annotated Bibliography that appears as an Appendix to this paper provide a conspectus of how some comparative law scholars have addressed the central questions evoked in this essay, and, where instructive, further characterization of some works cited in the footnotes. 
elaborate upon our argument by exploring what would be involved in the endeavour of teaching implicit comparative law.

One model for law teaching that incorporates the insights of implicit comparative law (and we acknowledge that there could be several such models) is reflected in what has come to be known as the "Transsystemic Programme" at McGill University's Faculty of Law. The architects of the Programme orchestrated a shift from a side-by-side presentation of civil law and common law courses, for example, contracts or successions, to a curricular structure that does not presuppose the salience of either civil law or common law traditions to the framing of course content. A transsystemic pedagogical practice is not exhausted by merely teaching an upgraded version of orthodox comparative law - comparative law 2.0, if you will - whereby a higher dimension of comparison or abstraction is layered onto traditional instantiations of bi-systemic or bi-jural investigations. Rather, transsystemic teaching and learning oblige participants - teachers, learners - to undertake a new inquiry into human interaction, human purposes, and the variety of normative modes and sites within which human agency is pursued. ${ }^{2}$ In its present and aspirational forms, the McGill Programme aligns with the aims and ambitions of the implicit comparative law approach that we present in this paper in that it tries to capture a practice of teaching and learning that is simultaneously pluralist, polycentric, non-positivist, interactive, and, of course, comparative.

In drawing on the McGill example, we could have organized our discussion of teaching implicit comparative law so as to focus on the macro level - an entire programme of undergraduate studies in law. Instead, to keep the scope of this paper manageable, we have chosen to imagine what the teaching of an individual course would entail if we were to adopt implicit comparative law as its

2. This conception of transsystemic teaching and learning is developed in Roderick A. MACDONALD, "Is Law a Zoo? ", Paper presented to the Annual Meeting of the Canadian Law and Society Association, Concordia University, Montreal, QC, 4 June 2010 [unpublished manuscript on file with the authors]. 
organizing framework. Again, we could have selected any law faculty course for this purpose. But to emphasize both the theoretical and methodological features of our approach, we have chosen to develop our argument by reference to (and in counterpoint to) the themes and objectives of traditional introductory courses on comparative law as these have been taught in the past at the Faculty of Law of McGill University.

Below, we present the main features of our proposed course in the form of a course syllabus, organized into the following sections: (A) Synopsis and Rationale, (B) Course Objectives, (C) Specific Learning Outcomes, (D) Primary Reference Materials, (E) Course Content and Pedagogical Approach, (F) Assignments and Assessment, (G) Feedback, and (H) Week-by-Week Outline of Seminar Sessions. ${ }^{3}$ The material we canvass under each of these headings, with the exception of the Outline of Seminar Sessions, is divided into two parts. In the first (italicized) part, we set out the actual content of the syllabus for our proposed course. In the second part, entitled Commentary, we point to and explore the bases of our curricular and pedagogical choices. The Commentary would not be distributed to students but rather is meant to serve as a Teacher's Manual of sorts. The italicized text could, consequently, be read straight through in its entirety, without reference to Commentary. ${ }^{4}$ Our discussion ends with an Annotated

3. This is not to say that the syllabus presented here exhausts the scope and content of a syllabus for an implicit comparative law course. Such a syllabus could also set out, for example, a detailed review of the obligatory course materials, teaching hours, class cancellations, office hours and instructor contact information, preparation for and participation in the course, pedagogical instruments (e.g. course website, discussion forum), and class-by-class learning outcomes. For a discussion of the considerations at stake in the process of syllabus construction, see Roderick A. MACDONALD, "Designing a Syllabus: A Nine-Yards Template ", Paper delivered at the Professing to Educate: Educating to Profess Conference at the Faculty of Law, McGill University, Montreal, QC, July 2003 [unpublished manuscript on file with the authors].

4. Moreover, as we hope will become clear in the course of working through the syllabus and the interspersed Commentary, the unusual organization of this essay is intended to reveal one possible framework for an implicit comparative law approach to legal study. We neither hold nor seek a 
Bibliography, in which we extend the exploration of the foundations and themes of implicit comparative law by providing a blueprint for deeper inquiry, engagement and reflection. ${ }^{5}$

Before turning to the elaboration of our course, we think it useful to foreground the three cardinal ideas about our understanding of implicit comparative law that will emerge as we work through the syllabus. First, we see the course itself as a site of law. Students will be challenged to notice how their approach to course materials and to the process of learning reflects the same intellectual activity as their approach to, and understanding of, law: students will be agents in the elaboration of the specific normative order constituted by their participation in the course. ${ }^{6}$ Second, the idea of implicit comparative law rests on a particular theory of law - critical legal pluralism - that rejects the premises of state legal positivism, the legal theory that invariably underpins orthodox approaches to comparative law. ${ }^{7}$ Third, the idea of implicit

monopoly on imagining - or setting the outer limits of - the spectrum of configurations for such an approach. Indeed, a cornerstone of the seminar we present here is the expectation that all participants will consistently reimagine and transform the approach we offer into their own understanding and practice of implicit comparative law.

5. Normally in a course syllabus, the Annotated Bibliography would follow the week-by-week outline of seminar sessions as an Appendix. But given the length of our bibliography and its pertinence to this paper as a whole, we have displaced the Annotated Bibliography to the very end of this essay so that our Conclusion (which, like this Introduction, is not actually a part of the syllabus) comes directly after the last substantive section of the syllabus.

6. Put slightly differently, the course is itself meant to be performative of what implicit comparative law entails as an intellectual endeavour. Hence, we conceive and present every feature of the course - teaching approach, materials, evaluations, feedback, etc. - in the light of this approach, suggesting in the accompanying Commentary the implicit comparative dimension of each section.

7. We acknowledge that many contemporary theories, such as that advanced by H.P. Glenn, also do not rest on the state legal positivist approach, even though they are not grounded in pluralist approaches. The basic premises of the critical legal pluralist hypothesis and their role in the implicit comparative law approach will be developed in the Commentary to section II.B of the syllabus. 
comparative law also rests on a specific conception of legal normativity - one that does not privilege explicit normativity of the type reflected in legislation and the outputs of bureaucratic lawapplying institutions like courts, but rather gives equal weight to practice, custom and purposive interaction as instances of an equally powerful tacit normativity inherent in all legal orders. ${ }^{8}$

\section{IMPLICIT COMPARATIVE LAW: A SYLLABUS}

\section{A. Synopsis and Rationale}

From almost our earliest moments, we learn to distinguish ourselves from other things in the world-animate and inanimate. As we grow, our capacity for recognizing the separateness and distinctiveness of things matures into a similar capacity for differentiating between behaviours and between ideas. At the same time, we develop a capacity to perceive similarity and to impose second-order categories to regroup what might initially appear to be disparate phenomena. Through these processes of differentiation and regrouping we seek to order our universe. Characterization and organization per genus et differentium are two of the many building blocks that enable us to expand the range of usable knowledge by which we orient our lives, undertake purposive actions and maintain intellectual coherence through time.

The modes and processes of our formal legal education are no different. For example, in Canadian law faculties, whatever the province, the core curriculum is organized around a prior (and usually unstated) definition of the field of inquiry (i.e. what constitutes law), and on canonical categories (public law, private law), sub-categories (property, obligations), and sub-sub-categories (contracts, torts, restitutionary claims) that we impose on certain legal norms, concepts, processes and institutions. Yet even as we learn to deploy

8. Given the emphasis on informal and implicit normativity it might be thought that the title of our proposed course should be Comparative Implicit Law, rather than Implicit Comparative Law. The distinction between the content captured by these two course titles is elaborated in the Commentary to section II.A of the syllabus. 
these taxonomies, we are also meant to learn the contingency of the assumptions upon which they rest, and the possibilities for alternative ways of organizing ideas and experiences. Often this insight comes from a careful analysis of cases and hypothetical situations that do not fit neatly into the pre-ordained categories. Other times, it comes from simply trying to imagine the world differently, particularly when our imagination is fired by some legally exogenous theoretical framework such as Marxism, welfare economics, or critical feminism. Occasionally, a course, a professor, a text or an assignment will aim to destabilize the known (the acknowledged body of legally relevant materials and ideas) by directly referencing the unknown (the exotic or more generally, the other). Conventionally, this extroversion to the unfamiliar, to the foreign, is, in law faculties, the province of comparative law.

The desire to expand intellectual horizons and advance the protocols for learning about the familiar through sustained engagement with the unfamiliar under a logic that presupposes the discovery or invention of similarity are the drivers of comparative legal study. Not surprisingly, comparative legal analysis - whether temporal or spatial - occurs every day in every course, usually without being expressly identified as such. For example, whenever you are subjected to a litany of hypothetical factual variations at the margins of a legal proposition - the so-called Socratic Method-you are being pushed to hone your capacity to characterize and differentiate on a comparative basis. In addition to comparison focusing on the minor premise of a legal syllogism (the facts), at some point or another, most courses engage you in the comparison of different modes of stating the major premise (the legal rule). Comparison of this latter type is the standard case of what scholars reference by the expression comparative law.

Where the call to engage in the comparative endeavour is explicit, and is a central objective of a course, the course title invariably signals the point, although not always with the word comparative. So, for example, temporal comparative law courses involving the comparison of legal propositions, concepts and institutions of a single legal order at different moments - invariably 
attract the epithet history as part of the title: Canadian legal history, history of private law, the adversarial system in historical perspective, and so on. Spatial comparative law courses, by contrast, are almost always labeled as comparative: comparative law, comparative legal traditions, comparative civil procedure, comparative medical liability, and so on.

We begin this course by considering orthodox approaches to the comparative study of law. These approaches rest on various assumptions about the meaning of law, the identity of legal actors, the purpose and value of comparison, the relationship between legal artefacts, the dynamics of normative interaction and norm migration, and the appropriate subjects of legal knowledge. Until recently, broad consensus has favoured these assumptions and the boundaries of comparative law they trace have been taken for granted. This is no longer the case. Contemporary comparative law scholarship is both theoretically and methodologically rich. Many monographs and articles focus on interrogating orthodox approaches to comparative legal study. Indeed, some comparative law courses today make such questioning one of the primary components of the tuition.

This course seeks to push inquiry of this latter type even further. We ask that you be willing not only to debate internal controversies about the province and function of comparative legal study, but also to challenge the givens of comparative law by actively questioning the givens of law. One might frame this intellectual endeavour as one of applied legal theory: must comparative legal analysis accept a state-centric, legal positivist conception of law as its epistemic foundation? how would the questions of comparative law be phrased if one were to adopt, for example, an anthropological or a sociological approach to defining law? or a Thomistic Natural Law approach? or a legal realist approach? or a critical race theory approach? or a law and economics approach? Posing these questions invites us to consider a brace of different theories of comparative law. 
In doing so, we will be studying the comparative law of comparative law. ${ }^{9}$

Although our comparative exploration is not intentionally polemical, we acknowledge that this course, like any other, has an identifiable underpinning and orientation. We entitle this course 'Implicit Comparative Law' because it rests on a particular theory of law - critical legal pluralism - that (1) draws no sharp pedigreeboundaries around the specific normative phenomena that count as law, and (2) accepts a multiplicity of normative systems not created or validated by the political state as meaningful comparative constructs.

Our instantiation of this course carries no claim as to its own necessity or sufficiency. We accept, as is consistent with a commitment to the critical legal pluralist hypothesis, that the curricular arrangements and coverage of implicit comparative law courses can be heterogeneous: multiple, flexible and variable. This said, you have before you the syllabus for a particular implicit comparative law course. This syllabus, like the syllabus of any other course, is the product of many inputs: it derives not just from orthodox perspectives on the subject; it is also shaped by our own understandings of the course's potential, which is inextricably rooted in the intellectual journeys we each took (and which we continue to pursue) to arrive at these understandings. Given the antifoundationalist premises of the course, we believe it important to state, as best we can, how this course came to be designed as it is. To that end, in the next few paragraphs, we briefly map our separate routes to this instantiation, of this course, in this faculty, at this time.

9. We have chosen to formulate the inquiry as the "comparative law" of "comparative law" rather than simply "comparative comparative law" because we see the endeavour of doing comparative law as itself normative. The different instantiations of inquiry, methods of exploration, modes of analysis and navigation between comparators at stake in carrying out the various theories and analyses - that is, the different manifestations and outcomes of the practice of comparative law - are not merely distinguishable on epistemological grounds. Rather, these variables diverge and collide in substantive and programmatic ways, ways with normative effect for the practitioners of comparative law. 


\section{Rod's intellectual journey}

For me, the idea of implicit comparative law arose from a rather belated realization that my approach to comparative law was grounded in a conception of law - state legal positivism - that was directly in opposition to beliefs I claimed to hold when I was doing legal theory or teaching my courses in administrative law and secured transactions. In these other courses I consciously adopted a critical legal pluralist theoretical framework. Once that light bulb went on, I began to explore how other scholars were teaching and writing about comparative law, and to compare that with how they taught and wrote about other legal matters. I discovered that a few, though certainly not the majority, were living the same dissonance between rich, contextualized conceptions of legal normativity as reflected in the substantive fields of their teaching and research, and the rather one-dimensional, state positivist conception of legal normativity that grounded the objects and processes of their comparative scholarship.

In undertaking this inquiry, I noted the preponderance of articles like "the officious intermeddler in common law and civil law", or "the German advantage in civil procedure", or "does the common law need a concept of "persons'?"or "existe-t-il un droit occidental?". Whether the comparison was of doctrinal structure or functional outcome, the objects of comparison were explicit artefacts of two or more political states.

More curiously, the scholarship of even those who claimed to be doing second-order comparative law theory was largely anchored in the comparative assessment of these artefacts. Whether the genus of inquiry was described as a "family" (as in Rheinstein), a "system" (as in Wigmore, in David and Brierley or in Schlesinger), or a "tradition" (as in Merryman), the different species being examined were almost always state legal orders. While some scholars also attended to religious legal orders (Daube), and customary legal orders (Malinowski), until my colleague Patrick Glenn brilliantly changed the register of inquiry and analysis, these other manifestations of law were largely consigned to the margins. 
Finally, I noticed that because the focus was on the law of the state, the normative contributions of all the other types of legal orders operative within a given community were not recognized as such, but were recharacterized as "fact". The traditional tropes "law in action", or "culture" or "brute functionalism" became handy covers for avoiding having to confront these recalcitrant "facts" as reflections of competing normative orders. The comparative endeavour was cast in one of two models. Many scholars sought to compare legal traditions associated with dominant political regimes - civil law, common law, socialist law, for example - or to compare variations on these generic categories: Italian civil law, French civil law, German civil law, on the one hand, and English common law and American common law, on the other. The other way of proceeding was to compare the legal systems of particular states, exploring the relationship between, say, the law of Quebec and the law of Ontario. Until very recently, few scholars sought to track the relationship between Quebec civil law and canon law, or between sharia law, Talmudic law and canon law as observed in Montreal, or between, say, any of the above and the living law of particular segments of the business community.

And so, I began to explore what would happen if I mapped my research (1) into the interactional bases of law, (2) into implicit and inferential legal normativity and (3) into legal pluralism onto my reflections about the scope and methods of comparative law. This course is the consequence of that effort.

\section{Kate's intellectual journey}

My formal interaction with implicit comparative law - that is, the first step on my intellectual journey towards this instantiation of this course - began when Rod introduced me to the term "implicit comparative law" and sketched for me one possible understanding of its meaning. My journey began, therefore, where the story of Rod's journey ends.

My first step naturally propelled a second. Being introduced to the idea of a body of knowledge and an approach called "implicit

comparative law" compelled me to reflect upon my own experience 
with what I understood comparative law (simpliciter) to be. In undertaking this reflection, I came to realize that my exposure to, and engagement with, comparative law up to that point could be wholly described in the language of doctrinal analysis, the functional approach and instrumentalism. These descriptors applied equally to my tenure as a masters student in law (my LL.M. thesis, written in conjunction with a graduate seminar on comparative law, was entitled "Resolving the 'Prisoner's Dilemma': A Comparison of Adversarialism and its Limits in England and Canada") and as a lawyer in traditional private practice (Is it more favourable for my client to pursue legal action in Canada or the United States? Should I invoke judicial interpretations of the Quebec Charter's privacy guarantees in my submissions on federal constitutional interpretation?). This methodological conception of comparative law was useful in the contexts in which I invoked it. However, as I have also realized, its narrow scope stands in tension with the comparative dimensions of my doctoral research, in which I position orthodox analyses and observations about an archetypal legal institution (the Supreme Court of Canada) beside alternatives in order to explore what can be learned about the nature of law from the study of the Court as an institution, and what can be learned about the Court as an institution from the study of the nature of law.

And so followed the third step on my journey: exploring how my understanding of "comparative law" fit with my understanding of "law" or, more accurately, with my growing sense of dissatisfaction with understanding law as merely an autonomous, top-down, statecentric phenomenon. Here, at this third step, it became clear to me that: (1) I was engaged in a process of deconstructing the hypotheses of implicit comparative law and of exploring the possibility of reconstructing those hypotheses in a personally compelling way; and (2) this process asked of me the same questions that I was facing as a doctoral student in law at the formative stages of scholarly inquiry and research design: What is law? What is legal knowledge? What are its sources, categories, methods, methodologies and institutions? How are they structured and ordered? With what does law (or do laws) interact? On what scale? How does our understanding of law shape our inquiry into it? How do conceptions of law impact law's 
institutional arrangements? And, the pivotal question underlying all the others, who am I in relation to law?

My contribution to this course reflects my efforts to answerand to urge you, as students of law, to pursue your own answers to - these questions. Ultimately, the steps on a journey towards an understanding of implicit comparative law are intermediate steps on the ongoing pursuit of understanding the interaction between law, society, knowledge and self.

$$
* * * * *
$$

\section{Commentary:}

A syllabus aims at answering a common student question, "why should I take this course?" It typically begins not only by introducing a course and providing an overview of its content (synopsis), but also by explaining how and why the course came to be (rationale). The synopsis and rationale just presented seek to incite student reflection about the foundations of legal knowledge.

Our course is anchored in the premise that comparison is a central component of the human quest for understanding. ${ }^{10}$ Characterization and taxonomy are methodologies by which we distinguish categories of knowledge and experience and by which we invent and differentiate components of knowledge and

10. If words matter, if actions matter, and if all human expressive communication matters (and we think they do), then the act and art of comparison, however carried out, also matter. Human beings constantly locate themselves and their artefacts by reference to their perceptions of others. As Jerome HAll, Comparative Law and Society Theory, Baton Rouge, Louisiana State University Press, 1963, p. 9 observed, "to be sapiens is to be a comparatist". Consider, as an example of the familiarity of comparative tendencies in everyday life, the multiplicity of linguistic devices by which we reference comparison. They include metaphor, simile, analogy, paradox, irony and imagery. Imagine the semantic deficit we would endure in the absence of these conventions. 
unmediated experience. ${ }^{11}$ This observation resonates in equal measure on the macro scale of all human knowledge and on the discrete micro scale on which particular disciplines and specific sets and fields of knowledge are plotted. Characterization and taxonomy are, on this account, vital instruments for discerning and assimilating legal knowledge. ${ }^{12}$

In legal taxonomy the criteria of genus and differentium are usually of two main types: the conceptual and the functional. The former posits features (whether phenomenal (sensory) or noumenal (cognitive)) by which particular identities may be established; the latter posits outcomes that particular identities produce or can be made to produce. But both approaches assume that legal knowledge exists prior to and independently of the commitments of the legal subject. In contrast, from a critical legal pluralist perspective, legal subjects are central to the creation, navigation and intersection of potentially competing legal orders. ${ }^{13}$ The exercise of comparative law is, therefore, not independent of individual commitments or the visceral human connection to comparison, but rather a manifestation of them.

11. On this account, characterization serves as the usual precedent of taxonomic efforts. Through characterization, the salient, primordial or distinctive features of an independent unit are, consciously or unconsciously, identified. The concern is one of essence. Taxonomy, however, in both conceptualization and execution, attends to the processes and schemes of classification. It implies the invocation of some system or arrangement of categories into which individual units can be slotted, distributed or classified.

12. One need only look to the American Restatements, the Canadian Abridgement, the Juris-Classeur in France or the organization of courses in any law faculty calendar as evidence of the taxonomic tendency in European and North American approaches to legal study. Of course, there is a significant difference between vehicles like the Juris-Classeur, the organization of which follows the conceptual structure of the Code civil des français, and encyclopedias like the Canadian Abridgement that follow an alphabetical presentation of topics. For a unique attempt to adopt the French model to the common law, see Andrew Burrows (ed.), Birks' English Private Law, 2nd ed., Oxford, Oxford University Press, 2008, and in particular the Introduction to the first edition (2000), edited by Peter Birks, at pages xxxv-li.

13. See section II.B and the accompanying Commentary, below. 
The scholarly attraction to comparative methods and subjects as touchstones of the study of law is signaled by the event for which this paper was written - the 50th Anniversary Conference of the Quebec Society of Comparative Law held in 2011. It is also reflected in the number of longstanding associations and institutions dedicated to promoting and advancing comparative law ${ }^{14}$ as well as in the enormous literary deposit of comparative legal materials that has amassed over time. ${ }^{15}$ In this modern flourishing

14. For example, the International Academy of Comparative Law (est. 1924), the American Society of Comparative Law (est. 1951), the British Association of Comparative Law (formerly the United Kingdom National Committee of Comparative Law) (est. 1956), the Swiss Institute of Comparative Law (est. 1982), the British Institute of International and Comparative Law (est. 1958), the Institute of European and Comparative Law (formerly the Centre for the Advanced Study of European and Comparative Law) (est. 1995), McGill's Institute of Comparative Law (formerly the McGill Institute for Foreign and Comparative Law) (est. 1965) and the Paul-André Crépeau Centre for Private and Comparative Law (formerly the Quebec Research Centre of Private and Comparative Law) (est. 1975). For general information on a number of these and other such associations, see Mathias REIMANN and Reinhard ZIMMERMANN (eds.), The Oxford Handbook of Comparative Law, Oxford, Oxford University Press, 2008.

15. See, for example, the extensive law library holdings in comparative law (e.g. a keyword search of the McGill University Library catalogue for "comparative law" reveals 21,779 holdings), prolific academic scholarship and engagement in the field (e.g. a sample of the English language journals includes the American Journal of Comparative Law, the International \& Comparative Law Quarterly, the Journal of Comparative Law, the Electronic Journal of Comparative Law, the African Journal of International and Comparative Law, the Islamic \& Comparative Law Quarterly, the ILSA Journal of International \& Comparative Law, the Singapore Journal of International and Comparative Law, and the Oxford University Comparative Law Forum), and government and policy reports that invoke comparison across regimes (e.g. UNIFORM LAW CONFERENCE OF CANADA, Strategic Lawsuits against Public Participation (SLAPPs) (and other abusive lawsuits), Ottawa, 2008, online: <http:// www.ulcc.ca/en/2008quebec-city-qc/235-civil-section-documents / 448-strategic-lawsuits-

against-public-participation-slapps-report-2008> (page consulted on July 25, 2013); Department of Justice, A Profile of Legal Aid Services in Family Law Matters in Canada, by Lorne D. BERTRAND et al., Ottawa, 2002). Not everyone sees this literary output as evidence of comparative law's flourishing. See, notably, Mathias REIMANN, "The Progress and Failure 
of comparative law, theoretical analyses often display an emerging disciplinary self-awareness. This self-consciousness is manifest in epistemic shifts amongst comparative law thinkers. One such shift moves the comparative reflexes away from an overriding focus on process and method to an interest in substance and purpose. Consider, to take an example, the shift in emphasis reflected in the decision of the Quebec association that brings together comparative law scholars to change its name from the Quebec Association for the Comparative Study of Law (a name implying a focus on process, method and the "how" of comparative law), to its present designation, the Quebec Society of Comparative Law (a name suggesting a concern with the substantive objects and ambitions of comparative law).

The post-WWII growth of comparative law has, however, given rise to a persistent orthodoxy that has (1) structured comparison as either essentialist or functionalist, (2) posited legal meta-phenomena (orders, systems, traditions and families) as the relevant categories of comparison, and (3) oriented the hypotheses of comparative law to the explicit, the formal and the momentary. Consider each component of this third characteristic of the orthodoxy. First, the analytical hypotheses of orthodox comparative law are focused on the explicit: whatever the method or subject of comparison, the artefactual comparator (norm, concept, domain of law, legal system, legal tradition) is a product of the modern political state or its surrogates, and whatever the unit of comparison (substantive or procedural rule, law-making or law-applying process, outcome), the focus is on practices and actions of officials and declarations by official institutions. Second, orthodox comparative law reveals its preoccupation with the formal insofar as it takes law to be an abstract, authoritative, exogenous artefact: law is to be identified by its pedigree, not by its purpose nor by the results that it in fact produces. Finally, the orthodox framework accepts the law as it exists at a given moment as its object: the comparison at stake is usually that of simultaneously existing 
regimes, rather than the mechanisms and processes through which the current state of affairs has come to be.

The orthodoxy we have just described is a necessary starting point for our proposed course. Without a firm grasp of the heritage and contemporary practices of comparative law, the idea of implicit comparative law is hard to fathom. However, it is a commitment to questioning orthodoxy's privileged place in the creation and perpetuation of legal knowledge that is the pedagogical propeller of this course: Why is the focus on artefacts and actions of the political state and not on the experiences and actions of individuals as legal agents? Why is law conceived of as an external force rather than a dynamic product of human interaction? And why is the comparative moment static rather than dynamic, aimed at facilitating the comparison of how even apparently unchanging formal legal artefacts and regimes evolve through time?

There is one other point we wish to make in the course Synopsis and Rationale. By setting out in parallel our separate intellectual journeys that led us to this course, we mean to illustrate for students that thinking about implicit comparative law also means thinking about the various reasons that have brought everyone together in the seminar. In a critical legal pluralist framework, the enterprise of comparative law requires attention to recognizing and comparing the different motivations and understandings of law held by seminar participants.

\section{B. Course Objectives}

We have designed this course with two foundational learning objectives in mind. These objectives flow from our rationale for creating the course as set out above. Both are directed to enriching your understanding of the forms of legal normativity and of the distinctive character of legal normativity by contrast with social normativity. 
First, by the end of the course, we hope that you will have acquired a more sophisticated understanding of legal normativity: law's rules, institutions, processes, and methods.

Even though this is not a conventional course in legal theory, achieving this first goal will require you to revisit some of the assumptions that underpin standard doctrinal approaches to the study of law. In particular, we ask you to challenge the assumption that the concept of legal normativity can be exhausted by reference to explicit, formal and consciously elaborated phenomena identified as belonging to a particular legal regime by an ex ante rule of recognition.

To aid this questioning, we present a model of normativity in which all the artefacts of law (norms, concepts, institutions, processes, methodologies) have multiple manifestations that can be plotted as coordinate points in a matrix formed by the intersection of two axes. The vertical axis plots degrees of conscious, institutional elaboration, spanning the explicit (official, conscious, chirographic) at the top to the implicit (interactional, unconscious, unwritten) at the bottom. The horizontal axis plots the extent to which the character of display and articulation of legal artefacts is canonical. This axis spans the formulaic (discursive, stipulative, detailed) on the left to the inferential (presentational, open-ended, more abstract) on the right.

The intersection of these two axes creates four quadrants. Consider how different kinds of legal rules and basic institutions, to take only two kinds of legal phenomena, can be plotted in these quadrants. In the upper left quadrant (explicit, formulaic) are the most recognizable or manifest kinds of legal rules (state-enacted legislation and regulations), and law making institutions (legislatures, courts, agencies, officials). In the upper right hand quadrant (explicit, inferential) are what might be called allusive legal phenomena. Here, we find rules announced in judicial precedents (ratio decidendi), and institutions that produce or interpret rules without themselves being designed for that purpose. In the bottom left quadrant (implicit, formulaic) are what we call routine legal phenomena, which include customary practices and informal 
business codes, as well as informal voluntary associations like standards associations and mediation services that make rules or apply them in settling disputes. Finally, in the bottom right quadrant (implicit, inferential) are latent legal phenomena, which include unwritten general principles of law, personal experience, and relationships based on trust.

The point of this complexification of normativity is, on the one hand, to enable you to see how much of the normative character of even official law is not "made" by official state institutions; and on the other hand, it is to assist you in recognizing how much law arises in everyday human interaction. Armed with such insights you may then begin to consider why both official and unofficial implicit normative phenomena must also be accounted for in any comparative legal exercise.

Second, by the end of this seminar, we hope you will have developed a more intentional and sophisticated understanding of what counts as law and what can reasonably be called a legal regime (or normative order).

To achieve this goal, you will have to reconsider what criteria you have adopted for distinguishing law from other types of normativity. We want you to ask: is it useful to quest for a sharp ex ante criterion to identify whether any given normative system or regime is a legal order? And, more particularly, if it were in fact possible to postulate some type of differentiating criterion, would this criterion relate the idea of law exclusively to the artefacts of the political state?

Traditionally, comparative law scholarship has taken as its primary object of study either the law of particular states or a genus of legal tradition (the civil law, the common law) that the law of these states instantiates. This tendency reveals comparativists' commitment to a formalist conception of law. Instead of finding the epistemological and ontological heterodoxy of contemporary legal theory reflected in different strands of comparative law discourse, we find a single ideology: state legal positivism. Several features 
characterize this perspective: there is a single legal order operative in a given geographical space at any one time; this legal order is the normative order authorized by the state; only rules that are made or recognized by official institutions such as legislatures and courts count as law.

As a result, the meta-framework of traditional comparative law is constructed on a notion of law as exogenous to, and imposed by the state upon, the individual. This commitment shapes scholarly choices about what constitutes an appropriate subject of comparative legal study: national institutional responses to human rights disputes, but not competing accounts of individual understandings of dignity; domestic same-sex marriage laws, but not the lived experience of competing familial relational rules; access to small claims courts and official mediators and arbitrators, but not access to everyday informal mechanisms of dispute creation, avoidance, and resolution.

In this course, we ask you to question the purchase of statecentricity on the Canadian legal psyche - whether in Quebec or any other province, but not of course, in Nunavut. 16 The legal pluralist hypothesis that grounds this course is meant to facilitate your interrogation. This pluralist hypothesis signals four ideas: (1) In any given environment, several legal orders are in direct competition for authority; (2) None of these legal orders derives its legitimacy from another legal order; (3) In any given environment, the state legal order is not necessarily the most powerful; and (4) The movement of legal rules and concepts between legal orders (including the state legal order) is bi-directional: sometimes, the rules of the state legal order

16. Alone among political jurisdictions in Canada, Nunavut does not have an underlying general law reflecting either the common law or the civil law tradition. Indeed, because of the disparate groups found in the territory of Nunavut, it is difficult to claim that there is even a single underlying general law (ius commune). To the extent they consider the question, citizens of Nunavut would not, therefore, see the enactments of the Canadian Parliament or the Territorial Legislature as comprising the paradigm case of law. 
penetrate into non-state legal systems; and sometimes the rules of non-state legal orders are imported into state legal systems.

In adopting a legal pluralist understanding of law as a starting premise for comparative inquiry, we legitimize the comparison of phenomena located in the allusive, customary and latent or tacit quadrants of the matrix noted previously. As a consequence, we are permitted, indeed, encouraged, to compare the interactional law of everyday life in multiple settings, across transient and evanescent micro-legal orders, as well as less transient, macro-normative orders, including even formalized supra-state legal orders (the law of the International Court of Justice and the law of the International Chamber of Commerce) and transnational non-state legal orders such as those internal to multinational corporations (the law of Toyota and Ford, of United Fruit and DelMonte, of Reebok and Nike), and religions (the Roman Catholic Church and the Eastern Orthodox Church).

The two first-order objectives of this course are meant to provide the foundation for the particular vision of comparative law that will be pursued in our examination of sites and modes of legal ordering. An expansive and pluralist account of what counts as law will enable you to see how comparative methodology can be deployed to juxtapose both manifest and latent legal artefacts and to understand the interaction of both official and unofficial legal orders.

$$
* * * * *
$$

\section{Commentary:}

The Course Objectives section of a syllabus should establish the inquiries through the pursuit of which a course moves forward. Accordingly, under the heading Course Objectives, we sought to answer the questions: What are the foundational premises of the course? And how are these premises elaborated in the organization of the course? 
Our first intended outcome for this course is to equip students with a framework for enlarging their comparative law analyses beyond a preoccupation with formal and explicit phenomena. Achieving this objective presupposes that students come to master a richer understanding of normativity in law generally. Traditional comparative law scholarship has two methodological foci: normative artefacts that are written (be these in the form of legislative enactments, regulations, or judicial decisions) and doctrinal analyses of these artefacts (whether measured by textual analysis of language or empirical studies of effectivity). Admittedly, many scholars who adopt these foci nonetheless acknowledge normative diversity. But when doing so, they usually tether the unofficial phenomena of which they take account to official law upon which the unofficial law is deemed parasitic.

Consider the following as an example of the comparative inquiry that would be engaged were we to adopt an enlarged conception of legal phenomena. We, the co-instructors of the proposed course (and co-authors of this paper), are a 64-year old male law professor and a 32-year old female doctoral candidate, both members of McGill University's Faculty of Law. Our everyday interaction is formally structured by the fact that the former is the latter's doctoral supervisor.

But is the formalized supervisory relationship set out by the rules of the Graduate and Postdoctoral Studies Office at McGill the only, or even the central, normative regime that governs our interaction? Imagine that we were writing an article comparing the supervisor-supervisee relationship in different countries, in different universities or in different departments of the same university. What elements of our relationship would we consider central to the analysis and what normative regimes would we hold to be significant? ${ }^{17}$ If we recall the four-cell matrix of normativity

17. See Desmond MAnderson, "Asking Better Questions: Approaching the Process of Thesis Supervision ", (1996) 46 J. Legal Educ. 407. 
outlined in the syllabus, we can compile a preliminary list of the applicable legal regimes:

(1) A number of manifest legal orders: the applicable legislative enactments of the governing bodies of Canada (the Criminal Code), Quebec (the Charte des droits et libertés de la personne), Montreal (City of Montreal By-Law 95-039, A By-law Concerning the Development of the McGill University Campus and Authorizing the Construction and Occupancy of a Building for the Faculty of Engineering), McGill University (Code of Student Conduct, employment regulations) and any applicable conventions and laws of the international legal order;

(2) Multiple allusive legal orders: a potential collection of judgments of a mutually-acceptable third-party dispute-resolution authority (whether mandated by McGill or agreed to by us); the manuals, handbooks and other documents prepared by professional associations and student groups that provide advice about the supervisory relationship;

(3) A plethora of routine legal orders: the customs, derived from university codes, social and professional negotiations and practices, and norms set out by the document that we have signed to regulate our relationship; in addition there are numerous secondary relationships arising in other dimensions of the interaction between us - our relationship as co-authors of scholarly work; the collateral relationship of referee and referent; and our projected relationship as co-teachers of a graduate seminar; and

(4) The powerful latent legal orders that sustain the other types of normative orders just reviewed: culturally-understood, but uncodified and often unconscious, normative orders arising from sites of identity (we share global, national, provincial and municipal citizenship, socio-economic band-width, and Western-European heritage); sites of culturally and socially-laden differences (we differ according to gender, age and social and professional status); and the evolving set of personal understandings that arise over time through everyday interaction (for example, the reputation we each 
bring to the relationship at its outset; the student's maturing scholarly judgment; the supervisor's growing acknowledgement of the increasing mutuality of intellectual contributions to joint projects). ${ }^{18}$

Contemporary conceptions of comparative law typically do not accommodate the uncertainty and movement of norms that are at stake in and between the varieties of normative orders described above. This remains true even though comparative law scholarship has shown increasing concern with the interaction of norms and their migration across borders (political, economic, social and ideological), systems (of whatever level of abstraction) and traditions (whether self-conscious or articulated by comparative scholars). ${ }^{19}$ In contrast, recognizing and engaging with diversity in every mode and site where one finds legal phenomena is a hallmark of the implicit comparative law approach. Unlike the traditional focus on the upper quadrants (and especially on the upper left quadrant) of the matrix, an implicit comparative law approach recognizes the

18. Our relationships with third parties add another layer of normative complexity to the analysis. We each have an independent professional relationship with one of McGill's Associate Deans; we have independent but mutual relationships with some other McGill Law faculty members, as well as with some of the supervisor's current and former students; we are in a tri-part relationship with the institutions to which the supervisor wrote letters of reference on the supervisee's behalf, McGill University as an institution, and the Faculty of Law. For further elaboration of the fourcell matrix, see the sources and diagrams cited in the Annotated Bibliography.

19. For a discussion of internormativity, transplants and harmonization as conceptions of norm migration, see Roderick A. MACDONALD, "Les vieilles gardes : hypothèses sur l'émergence des normes, l'internormativité et le désordre à travers une typologie des institutions normatives " in Jean-Guy BELley (ed.), Le droit soluble: Contributions québécoises à l'étude de l'internormativité, Paris, L.G.D.J., 1996, p. 233 and Roderick A. MACDONALD, "Three Metaphors of Norm Migration in International Context ", (2009) 34 Brooklyn J. of Int'l L. 603. For a discussion of the appropriateness (of lack thereof) of invoking certain metaphors to describe the movement of norms, see: H. Patrick. GLEnN, "On the Use of Biological Metaphors in Law: The Case of Legal Transplants ", (2006) Journal of Comparative Law 358. 
comparative possibilities of commensurable units regardless of their coordinates.

Our second first-order objective for this course is that students will challenge the notions that authorization by the political state is the criterion for distinguishing legal and social normativity and that a state-centric framework is inevitable in legal study. While the comparative enterprise's preoccupation with legal phenomena emanating from the political state is not unexpected given some of the objectives attributed to comparative law, ${ }^{20}$ some comparative law scholars struggle with the constraints of traditional methods and categories. These analytic discomforts and their prescriptions for relief - often germinate within the domain of comparative law and grow outwards. As a result, both the diagnoses of, and the prescribed remedies for, comparative law's pathologies are framed in traditional terms. That said, alternative sources of relief from the malaise of orthodoxy have emerged from

20. That is, if the objective is, for instance, to respond to the demands of crossborder legal practice and the boom of international business transactions, then the comparative exercise can be conducted at an initial stage by exclusive reference to the institutions, processes, norms and practices of the state. See Roderick A. MACDONALD, "Transnational Secured Transactions Reform ", (2009) Zeitschrift fur Europaisches Privatrecht 745. In such cases, the value of the comparative exercise is measured in terms of market expansion, globalized career opportunities and consumer demand. Correspondence between the purpose and method of comparative law also exists (in a self-fulfilling way) if the goal is to classify legal systems into families or traditions on the basis of official, institutional responses to certain problems, to assist judges in filling gaps in the law or to achieve legislative unification, harmonization and/or reformation. On this view, competing non-state normative orders can be discounted as secondary, as parasitic upon the state legal order, and as evidencing mere states of fact illustrating the inevitable difference between "legal cultures". For further discussion of these themes, see R. A. MACDONALD, "Is Law a Zoo? ", supra, note 2. See also, for an example of measuring the "unofficial" against the "official", in this case, informal economies against the gross domestic product, see Friedrich SchneIDer, Andreas Buehn, and Claudio E. MonTEnEGRO, "Shadow Economies All over the World - New Estimates for 162 Countries from 1999 to 2007 ", (2010) Policy Research Working Papers 5356, online: <http:/ / elibrary.worldbank.org> (page consulted on July 25, 2013). 
studies of structural connections between instantiations of microlegal orders (the law of everyday life) and macro-legal orders. ${ }^{21}$ Such exercises, which adopt legal pluralist premises and work inwards towards comparative law, offer insight into the mechanisms of situating official and unofficial law in each other's comparative gaze.

Our proposed course, however, goes beyond simply comparing non-official micro- and macro-legal orders with official state law. Course participants will step both analytical feet outside the realm of official law and into a domain that accepts non-official law as legitimate on its own terrain. Pursuant to this approach, neither the state nor official agencies of law-making or lawinterpretation are required to provide an institutional locus for distinguishing real law from other forms of normativity. While many legal pluralists adopt a social scientific conception (which seeks to find in actual normative orders the equivalent institutions, rules and practices of state law), others (including the authors of this paper) take a conception of law in which a legal order is constituted (that is, legitimated as law) not by any institutional claim it makes of legal subjects, but by the legitimacy that leg al subjects accord to that legal order and its claims. ${ }^{22}$ The pluralist perspective

21. Daniel Jutras, "The Legal Dimensions of Everyday Life ", (2001) 16 C.J.L.S. 65 (which identifies the "architectural continuity" between brief encounters and formal, institutionalized human interaction, as manifested in shared tensions and polarities across the normative orders and along the axes of (1) the interdependence of norms and power and (2) the operation of explicit and implicit normativity). See also Lon L. FULLER, "The Law's Precarious Hold on Life ", (1968-1969) 3 Ga. L. Rev. 530; W. Michael ReIsman, Law in Brief Encounters, New Haven, Yale University Press, 1999 (which uses official law as a means of illuminating the characteristics of everyday life as an interactive legally-ordered space); Roderick A. MacdonALd, Lessons of Everyday Law, Montreal, McGillQueen's University Press, 2002 (which invokes the allegorical potential of everyday life to illuminate fundamental problems of macrolegal ordering). Consider also Justice Albie SACHS, The Strange Alchemy of Life and Law, Oxford, Oxford University Press, 2009.

22. This is not to say that there is no criterion by which to assess these claims. But, the processes of characterization and assessment are, foremost, matters of personal judgment and the criteria relied on, whatever they might be - neutrality, coherence, justice, predictability, liberty - are reflections of the legal agent. For a discussion of criteria for distinguishing 
underlying this course embodies an understanding that law is present wherever people are engaged in symbolizing human conduct (both their own and that of others) as governed by rules. This they do whenever they reflect on the relative weight they afford to competing normative claims, whatever the source or type.

\section{Specific Learning Outcomes}

We aim to build on the course rationale and the first-order objectives set out above by attaching two specific learning (or secondorder) aims to the substance and pedagogy of this course and striving to assist each of you in your pursuit and attainment of these goals. We hope that through the course tuition, you will encounter questions, resources, and methodologies that will empower you to transform the course into an intellectual endeavour that is meaningful for you and your colleagues. The second-order objectives that we identify here are primarily concerned with encouraging you to confront your own position in relation to the more complex conceptions of law and legal normativity described above. In other words, we ask you to interrogate your understanding of your own legal identity and agency, as well as the legal identity and agency of each participant in this course. We will pursue these outcomes collectively, but their ultimate attainment will attach at the individual level.

Our first second-order objective is that, by the end of the course, you will have cultivated a more complex understanding of your own position in relation to conceptions of law.

legal and social norms and normative orders, see Roderick A. MACDONALD, "Triangulating Social Law Reform ", in Y. Gendreau (ed.), Dessiner la société par le droit, Montreal, Éditions Thémis, 2004, p. 119. Further, a legal agent may find authority by virtue of the wisdom of others: "The manifestly foolish human being, interacting with others, is a law-maker and a law-applier, but no one accepts her or his actions as authoritative; by contrast, the wise human being, engaged in the same activities, can be taken to be an authority, and other human beings - even as agents - will defer to her or his understandings": Roderick A. MACDONALD, "Custom Made - For a Non-chirographic Critical Legal Pluralism ", (2011) 26 C.J.L.S. 301 , note 32 . 
To achieve this goal, we want you to interrogate your usual position as external to law: Are you a legal subject constituted by law, or are you a law-creating legal agent? To facilitate this endeavour, we adopt a critical legal pluralist hypothesis - and the agent-centred conception of law at its heart - as a premise of this course. According to a critical legal pluralist account, the "legal subject" posits the self as the irreducible site of normativity and internormativity and understands that all human individuals are, in their social interaction, law-makers and law-appliers. Put otherwise, your primary concern in this course will not be with how law (especially official law) treats you. Rather, your focus will be the ways in which you apprehend, constitute, remake and deny law orin other words - how you treat law.

Such an orientation immediately requires you to confront all those types of law that are not explicitly made. These can be grouped under the idea of "tacit" or "implicit" law. This idea does not just refer to the unwritten rules of the official legal order that sustain and nourish the state's legislative and judicial processes or the unenacted general principles, customs, and usages that may be recognized by national and sub-national courts. While these understandings correctly conceive of implicit law as arising in human interaction, they incorrectly presume that interaction generates implicit law exclusively vis-a-vis its ties to the existing explicit legal order.

Traditional models of comparative law do not account for the full dimensions of implicit law; the model of implicit comparative law presented in this course does. To engage in an implicit comparative law analysis is to reject the orthodox assumption that the artefacts of official law are the exclusive units of comparative concern, accept that the comparative mediator is the individual legal agent (i.e. the individual who makes, applies and lives the law and who navigates and recounts the interaction of normative orders), and embrace the implicit law reflected in the normativity emergent in the reciprocal adjustment of expectations that legal agents have of each other. Accordingly, implicit law, and the interaction that generates it, may 
unfold and exist independently of any acknowledgement, approval or authorization of an official legal institution.

The second specific learning outcome rests on our cardinal intention that this course be self-reflexive. You are meant to apply the protocols of the implicit comparative law approach to your own understanding of how all your other legal activities are pursued. The syllabus you have in front of you is, at best, the equivalent of explicit and formulaic normativity - the normative hypothesis of a law-maker (in this instance, the course instructors). Accordingly, each of you is encouraged to develop your own individualized syllabus for the course, making use of the entire range of explicit and implicit normative resources that we canvass during the academic term. Moreover, to maximize the reflexivity of this transformation process, you should strive to interact with all the course participants as they undertake the same exercise.

At bottom, the personal learning syllabus that each of you creates for yourself is the most important outcome to which the course aspires. The ambition is that you will extend the comparative exercise to the enterprise of learning, by considering how you and your classmates have come to understand the diverse possibilities, as well as the potential limits, of learning law that are opened up by the implicit comparative law hypothesis. After all, if that hypothesis is valid, every participant in this course is at one and the same time, a teacher and a learner. Throughout the semester we will constantly be asking ourselves whether we are making the most of our own learning/teaching experience.

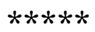

\section{Commentary:}

The specific learning outcomes set out in a syllabus are statements of aspiration. Our stated outcomes are attempts to answer the questions: What skills and knowledge bases do we hope that students will develop in this course? What personal journey do 
we hope that the course participants will embark on during the course and take with them beyond the classroom?

Our first second-order objective for this course is that students will interrogate their usual submissive, external place visà-vis law. Hence, our explicit commitment to a critical legal pluralist approach. Indeed, this course rests on the claim that a critical legal pluralist hypothesis is at once, the foundation of implicit comparative law and the necessary outcome of implicit comparative law in action.

Consider first the foundational premise, which is illuminated by articulating propositions central to the critical legal pluralist hypothesis. First, for a critical legal pluralist, the individual - the legal subject and legal agent - is the locus of normative interaction. ${ }^{23}$ Second, the analytical focus is on contingency, agency and pervasive heterogeneity in individuals' imagination and engagement with multiple applicable legal orders ${ }^{24}$ and these

23. "A radical legal pluralism [for the purposes of this text, this phrase should read "a critical legal pluralist approach"] presumes that legal subjects hold each of their multiple narrating selves up to the scrutiny of each of their other narrating selves, and up to the scrutiny of all the other narrated selves projected upon them by others. In doing so, we acknowledge that our multiple selves are constituted by these multiple reciprocal gazes, and that because they have the potential to multiply themselves through each reciprocal gaze, the number of possible selves is limitless: it grows exponentially at, and with, each gaze. In brief, particular legal subjects are constituted, shaped, remade, denied and destroyed through the knowledge and identities they inherit, create and share with other legal subjects": Roderick A. MACDONALD, "Here, There... and Everywhere: Theorizing Legal Pluralism; Theorizing Jacques Vanderlinden ", in Lynne CASTONGUAY et Nicholas KASIRER (ed.), Étudier et enseigner le droit: hier, aujourd'hui et demain - Études offertes à Jacques Vanderlinden, Montreal, Éditions Yvon Blais, 2006, p. 412-413.

24. Critical legal pluralism embodies heterogeneity (plurality embraces complexity not only numericality); flux (power distribution dynamics are central to tracing trajectories of normative interaction); and dissonance (systemic coherence is problematic within any given spatial, temporal, social or affective fields). See Roderick A. MACDONALD, "Critical legal Pluralism as a Construction of Normativity and the Emergence of Law ", in 
constructive endeavors take place every day in numerous sites and through numerous practices. Finally, the multiple normative outputs negotiated in these constructive endeavours are more than social practices - they are the reflection of discrete, yet interpenetrated, legal regimes. Put another way, these propositions of the critical legal pluralist approach provide that both law's creation and the processes of internormativity require legal agents to engage in, and understand the legal enterprise as, a taxonomic and comparative negotiation of the myriad explicit and implicit legal orders at play in any particular interaction.

Now consider the action premise. A critical legal pluralist approach does not describe given entities in the world. Rather, it acts as a heuristic device for analyzing patterns of social and normative interaction; identifying contingent relationships between norms, methods of ordering, modes of symbolizing and specific social milieu; analyzing normative continuity and change over time and space; describing differing intensities of normative interaction among various actors; and modeling mutual adjustment among legal orders. On this model, the most basic inquiries are obviously not concerned with how law interacts with society, but rather with how different legal normativities within society interact. Moreover, by positing that normative argument not be short-circuited by claims of systemic priority, this critical legal pluralist approach exposes the contingency of normative concepts operative within given regimes and requires the development of modes of argument and reasoning that recognize plural sources of normativity.

Taking the foundational and action premises seriously entails understanding that the interaction between different legal regimes cannot be exhausted simply by comparing when, how and why one legal order officially adopts - or should adopt - the norms of another. Normative conflict, migration and transplantation originate not in overlapping or parallel explicit orders, but rather in the everyday experience of the legal agent. The inquiry starts by

Andrée LAJOIE et al. (eds.), Théories et émergence du droit: pluralisme, surdétermination et effectivité, Montréal, Éditions Thémis, 1998, p. 20. 
accepting that examining diverse instances of internormativity is to take seriously, for each site of legal production, the conceptual apparatus inherent in it. It is to presuppose that individuals themselves (be they officials or not) set the conditions under which they undertake inter-normative dialogue. In this exercise, each legal regime will be understood both as subject - having its own conception of 'sources of law' and criteria of jurisdictional porosity - and as object - subject to incorporation into another legal order, notwithstanding its own self-conception, on terms established by that other order.

The second specific learning outcome that we have set for this course focuses on the reflexivity of teaching, learning and ultimately, of law. It signals our aim to amplify the intentionality of comparative legal study and to enlarge and optimize both the aspirational and the practical aims of the endeavour. Our ambition to attain these aims is grounded in two articles of faith. First, we believe that each course participant - student, instructor - will, as the semester proceeds, create his or her own course. That is, the formal course tuition as reflected in the syllabus is only a part of the comparative endeavour that each student will undertake. Through the various exercises and assignments, in combination with the divergent constellation of normative commitments that each one brings to the seminar, students will construct a course that is unique to them. The seminar will become, therefore, for each student, his or her own site of law.

The complementary belief driving our commitment to reflexivity is that, in developing these individual courses, every student in the course will interact with every other student. We believe that the richest form of comparative learning involves assessing one's own actions and assumptions in the light of the actions and assumptions of others. At bottom, the implicit comparative law hypothesis is that the greater the number of sites of comparison in any learning environment, the deeper the understanding not just of law, but of comparative law. And the sites of comparison can never be fully stipulated in advance; each new site being explored opens a previously unknown range of other potential 
sites. This is the tacit dimension of knowledge that is signalled by the notion "implicit comparative law". 25

\section{Primary Reference Materials}

We have compiled the obligatory materials for this course into a compendium of, first, written and graphic works and, second, instructions for accessing non-textual and non-still (e.g. video, musical, theatrical, and multi-media) works. The compendium can be downloaded from the course website or photocopied from our master version, which we will bring to class.

You may wish to complement or supplement the works provided for in the compendium by accessing reference materials that mine the primary themes of this course to their epistemic and conceptual bases. Below, we list primary reference works in four expansive categories that lie at the core of our configuration of this course - (1) the foundations of comparative law, (2) transsystemia, (3) legal pluralism and (4) implicit law. Each of the reference materials listed below is available either on the course website (articles) or at the reserve desk in the Law Library (texts). Additional routes for exploring these (and related) areas of inquiry are mapped in the Annotated Bibliography (Appendix).

(1) Our study of the traditional North American and Western European approach to comparative law compels us to confront the "masters" of the field. The classical literature is rich and voluminous. You could begin an instructive foray into the field by familiarizing yourself with the form, substance, and evolution of the following authoritative texts:

25. For a discussion of the epistemic assumptions of the tacit dimension of knowledge - that is, the knowns and unknowns underlying individual knowledge - at stake in implicit comparative law see Michael PoLANYI, Personal Knowledge, New York, Harper Torchbacks, 1956 and Michael PolanyI, The Tacit Dimension, Garden City, Doubleday, 1966. 
Arthur VON MEHREN and James R. GORDLEY, The Civil Law System: An Introduction to the Comparative Study of Law, $2^{\text {nd }}$ ed., Boston, Little Brown \& Co., 1977.

Konrad ZWEIGERT and Hein KOTZ, An Introduction to Comparative Law, $3^{\text {rd }}$ ed., Oxford, Clarendon Press, 1998.

René DAVID et Camille JAUFFRET-SPINOSI, Les grands systèmes de droit contemporains, $11^{e}$ éd., Paris, Dalloz, 2002.

H. Patrick GLENN, Legal Traditions of the World: Sustainable Diversity in Law, 4th ed., New York, Oxford University Press, 2010.

A rich compilation of recent, varied perspectives on the development of comparative law in certain regions of the world, on approaches to comparative law as an intellectual endeavour, and on the state of comparative studies in particular areas of law is found in:

Mathias REIMANN and Reinhard ZIMMERMAN (eds.), The Oxford Handbook of Comparative Law, Oxford, Oxford University Press, 2008.

Moreover, the tuition in this course is premised on a concern with the individual legal subject's centrality to comparative legal knowledge, processes and practices. For helpful development of this theme, see:

Roderick A. MACDONALD, "Custom Made - For a Nonchirographic Critical Legal Pluralism"(2011) 26 C.J.L.S. 301 .

2) The McGill Faculty of Law's transsystemic curriculum is the culmination of evolving institutional commitments to an ongoing, open conversation with law over time. Transsystemia is 
neither uniform in concept nor static in execution. Nevertheless, its current instantiation at McGill reflects a curricular theory and practice that offers much insight into the ambition and actualization of implicit comparative law. If you are looking for discussions that foreground the McGill Programme's evolution and methodological approach, the following sources will be of assistance:

Roderick A. MACDONALD, "The National Law Programme at McGill: Origins, Establishment, Prospects ", (1990) 13 Dal. L.J. 211.

Yves-Marie MORISSETTE, "McGill's Integrated Civil and Common Law Program ", (2002) 52 J. Legal Educ. 12.

Nicholas KASIRER, "Bijuralism in Law's Empire and in Law's Cosmos ", (2002) 52 J. Legal Educ. 29.

Alternatively, for accounts of transsystemic pedagogy and the experience of a transsystemic classroom, look to these two articles:

Roderick A. MACDONALD and Jason MACLEAN, " No Toilets in Park ", (2005) 50 McGill L.J. 721.

Jacques P. VANDERLINDEN, "Une lecture du système normatif de l'Église catholique par un pluraliste comparatiste aux personnalités multiples ", (2005) 50 McGill L.J. 809.

Finally, if you are seeking help in constructing a framework for assessing the McGill Programme's successes and failures, its versatility and singularity, the following two articles will provide you with some starting points:

Harry ARTHURS, "Madly off in One Direction: McGill's New Integrated, Polyjural, Transsystemic Law Programme ", (2005) 50 McGill L.J. 707. 
Peter L. STRAUSS, " Transsystemia - Are We Approaching a New Langdellian Moment? Is McGill Leading the Way?", (2006) 56 J. Legal Educ. 161.

(3) "Legal pluralism" signifies a range of hypotheses about law that point to non-monist accounts of the forms, sites, modes, meanings and/or trajectories of law. The critical legal pluralist approach that underlies this course is a response to the dominant narratives of contemporary pluralist legal scholarship. One of the instructors of this course has elaborated on the foundational principles of critical legal pluralism and its position vis-à-vis other strands of legal pluralist thought in an extensive scholarly corpus. The principal accounts are found in:

Martha-Marie KLEINHANS and Roderick A. MACDONALD, "What is a Critical Legal Pluralism? ", (1997) 12 C.J.L.S. 25.

Roderick A. MACDONALD, "Critical legal Pluralism as a Construction of Normativity and the Emergence of Law" in Andrée LAJOIE et al. (eds.), Théories et émergence du droit: pluralisme, surdétermination et effectivité, Montréal, Éditions Thémis, 1998, p. 9.

Roderick A. MACDONALD and David SANDOMIERSKI, "Against Nomopolies ", (2006) 57 Northern Ireland Legal Quarterly 610.

Roderick A. MACDONALD, "Here, There... and Everywhere: Theorizing Legal Pluralism; Theorizing Jacques Vanderlinden " in Nicholas KASIRER (ed.), Étudier et enseigner le droit: hier, aujourd'hui et demain - Études offertes à Jacques Vanderlinden, Montreal, Éditions Yvon Blais, 2006, p. 381.

(4) The concept of "implicit law" is not new or unique to this course. A number of scholars have undertaken the task of exploring its foundations and considering the relationship between implicit 
forms of normativity and official legal institutions. The following sources are especially helpful in this regard:

Lon L. FULLER, Anatomy of Law, New York, Frederick A Praeger, 1968.

Lon L. FULLER, "Human Interaction and the Law", (1969) 14 Am. J. of Juris. 3.

Gerald POSTEMA, "Implicit Law" in Willem J. WITTEVEEN and Wibren VAN DER BURG (eds.), Rediscovering Fuller: Essays on Implicit Law and Institutional Design, Amsterdam, Amsterdam University Press, 1999, $p$. 255.

Jeremy WEBBER, " Legal Pluralism and Human Agency ", (2006) 44-1 Osgoode Hall L.J. 167.

Roderick A. MACDONALD, " Unitary Law Re-form, Pluralistic Law Re-Substance: Iluminating Social Change ", (2007) 67 La. L. Rev. 1113.

Kristen RUNDLE, Forms Liberate, London, Hart Publishing, 2012.

$$
* * * * *
$$

\section{Commentary:}

In the design of a course, considerable effort must be devoted to developing a set of obligatory course materials, as well as a list of complementary readings. Our criteria for selecting obligatory materials are closely tied to our course objectives. Obligatory materials are not simply a portable library of substantive texts that cover the topics of each class session. They must also speak to all course objectives, including pedagogical goals, and the set of skills (oral and written communication, institutional design and instrument choice, integration and transformation of material, the 
recognition and resolution of ethical dilemmas) that are inherent in all deep learning. This is why the use of websites, other external linkages, and materials in non-written and fluid forms is a necessary feature of our implicit comparative law course. To date, few doctrinal writings present the problems of implicit law and we have found none that address our concern with implicit comparative law. Most of our compulsory sources, consequently, are drawn from everyday human experience and do not show up in any indexes of law or comparative law.

The complementary references listed in this section have another purpose. Here the goal is to provide students with references to some foundational writings about key course themes. We have purposely selected materials that take provocative positions and that have extensive bibliographies. We have sought to select materials that instantiate pluralist themes and that will enable students to locate their own emerging understandings within the intellectual traditions of contemporary reflection on comparative law. While some reflect our own views, other texts are intended to provide counterpoints. The Annotated Bibliography in the Appendix provides a further resource of this type. Our assumption is that course participants will have an occasion, in reading these further sources, to apply research and analytical protocols addressed in the seminar to evaluate the assumptions that authors make, and to hone their critical capacity to ferret out the implicit dimensions of the comparative exercise that these authors are undertaking. ${ }^{26}$ Moreover, we conceive of these materials as complementary to signal that each member of the seminar is expected to actively seize the role of agent in the individual intellectual journey and comparative practice on which he or she has embarked and of which this course is a part.

26. The approach to scholarship implicit in our selection of materials is derived from Susanne K. LANGER, Philosophy in a New Key: A Study in the Symbolism of Reason, Rite, and Art, 3rd ed., Cambridge, Harvard University Press, 1957. 


\section{E. Course Content and Pedagogical Approach}

In this course, we begin by asking comparative questions about comparative law. We ask you to reflect upon the mainstream view of comparative law and to inquire into the reasons for its historical monopoly of the field. This inquiry has two dimensions. One is historical. Consider whether comparative law would now be framed as it is if the first such endeavours were products of the late $18^{\text {th }}$ or the late $20^{\text {th }}$ rather than the late $19^{\text {th }}$ century. The other is conceptual. Consider whether the approach to comparative legal study in different parts of the world (North America, South America, Europe, Africa, Asia), or even in different countries (for example, Japan, Germany, Israel, the United States) reflects any features (historical, geographic, political, demographic) that may be specific to such regions or states. To facilitate these tasks and to pursue their implications throughout this course we juxtapose mainstream views with our alternative approach, which we label implicit comparative law. The comparative endeavour announced by this title speaks not only to the ostensible subject matter of the course but also to its pedagogy.

The section of this syllabus on specific learning outcomes indicates that the scope of the topics covered in the course and our pedagogical approach are grounded in a particular legal theory critical legal pluralism. What does it mean to teach and learn comparative law taking such an approach? The following example, taken from a hypothetical fact situation that we will address at length in our initial class, is offered as an illustration of how we will weave content and pedagogy together in this course. The hypothetical is drawn from the general universe of commercial transactions and, more specifically, from the field of inventory financing. Our goal is to inquire into (1) the legal regimes that are intended to regulate the distribution and sale of snowmobiles in Rouyn, Quebec, in Hawkesbury, Ontario, in Geneva, Switzerland, and in Thredbo, Australia, and (2) the legal systems that aim to regulate the distribution and sale of automobiles in Montreal, Quebec, in Toronto, Ontario, in Paris, France and in London, England. The course materials will introduce you to the official regulatory schemes in place 
in these different political jurisdictions (Civil and Commercial Codes, common law cases, Personal Property Security Acts, and so on). As you are reviewing these materials, you should ask yourself exactly how you are engaging in a comparative analysis. What are the normative regimes that provide the legal framework through which different sets (and forms) of materials may be regrouped? With respect to each regime, what is the genus that provides the common ground for comparison? And what are the criteria of differentiation that define the matrix onto which you might plot your comparative observations?

In an orthodox exercise of comparative law, we would likely begin by identifying the legal family or tradition to which the official law of each of the particular cities in question belongs. Assuming that we are studying at a law faculty in Quebec, in such an exercise we would initially regroup the eight sites according to the political unit (Quebec, Ontario, England, France, Switzerland, and New South Wales) where they are located. But orthodoxy would see little interest in comparing sites of law in the same political jurisdiction (for example, Hawkesbury and Toronto, or Rouyn and Montreal). So a complementary opening reflex would be to regroup these cities as being located in either civil law or common law jurisdictions. Once this is done, a doctrinal comparison could then be organized by exploring the official law applicable to financing snowmobiles in, for example, Rouyn, Quebec, and Hawkesbury, Ontario, or more generally the official law of secured financing common to Rouyn and Montreal (and more remotely Paris and Geneva) with the official law common to Hawkesbury and Toronto (and more remotely London and Thredbo).

Why, however, are these particular groupings our first comparative reflex? When and why does the official law of a Civil Code or a Personal Property Security Act achieve pride of place in the way we organize different normative regimes? To answer, we need to examine the assumptions about law, legal knowledge, identity and difference, legal subjects and legal agents that ground this comparative exercise - assumptions that are both explicit and implicit in the way we have been learning the law to this point in our law 
faculty careers. Since we know that there can be other conceptions of what characterizes a normative regime, there must likewise be different criteria by which regimes may be grouped and compared. Under what criteria of similarity might we consider the primary cognates to be Rouyn and Hawkesbury (and more remotely Geneva and Thredbo) on the one hand, and Montreal and Toronto (and more remotely Paris and London) on the other? Here, we only need imagine that the foci of our comparative inquiry are the object of the transaction (snowmobiles or automobiles) and the character of the retail market for those objects. Might it also be possible that the primary cognates are old world cities (Paris, London and Geneva) as against new world cities (Toronto, Montreal, Rouyn, Hawkesbury, and Thredbo)? Still again, are there not conceptions of normative regimes in which the primary cognate pairs might even be Rouyn and Toronto on the one hand, and Montreal and Hawkesbury on the other? Or might they be Paris and Thredbo (and more remotely London and Geneva) on the one hand, and Montreal and Toronto (and more remotely Rouyn and Hawkesbury) on the other? For such to be the case we need only consider how patterns of trade, internal corporate distribution mechanisms, and inventory and consumer financing opportunities might affect trade practices and customary norms that develop around these practices.

As you think through these hypotheses you may also wish to consider what impact, if any, different professorial approaches to the transsystemic teaching of private law at McGill may have on your susceptibility to notice and analyze these various normative regimes. Suppose that the target of transsystemic teaching in one professor's course is to explore the extent to which diverse variations on the common law tradition (say, England, U.S., Canada, Australia, New Zealand, India) could be mapped onto diverse variations on the civil law tradition (Germany, France, Italy, Spain, Quebec, Brazil). Then suppose that for another professor the endeavour is to consider whether civil and common law traditions are each just instantiations of a larger intellectual construction - the western idea of law - and that richer comparative insight could be gained by comparing these western traditions with the ensemble of monotheistic religious traditions - for example, Islamic law, Talmudic law, and Canon law. 
Contrast both these approaches with transsystemic teaching that is grounded in a legal pluralist approach that privileges chthonic normative regimes like those instantiated by diverse aboriginal legal systems in Canada and the United States. Such an exercise shows that adopting an implicit comparative law framework invites inquiry into the different ways you might compare the transsystemic teaching you have been experiencing in your various courses at McGill.

As for the pedagogical approach in this course, it is important to signal that the legal pluralist hypothesis grounds every feature of the tuition. It frames the manner in which different normative orders operate and interact across the range of substantive topics and themes - rules, concepts, procedures, institutions, methodologies, and approaches to teaching and learning law - we address. It influences our approach to communication both in and beyond the classroom. The formal languages of instruction in the course will be English and French, but on several occasions some other symbolic discourse - music, dance, art, film and mime, for example - will be adopted. Course materials will be equally polyglot. Moreover, since the course is meant to uncover the implicit normative orders that shape the legal manifold regimes operative in a given social space, our pedagogical practices will also vary from class to class. All sessions will be interactive and problem-based, using various horizontal, participatory formats, including role-playing, small group break-outs, inverted debates, jury-room processes, and talking circles. About onethird of the sessions will actually be led by you rather than us.

$* * * * *$

\section{Commentary:}

In the Course Content section of the syllabus, we have tried to show the close connection between form and substance in an implicit comparative law course. The point is that the two questions, "What is this course about?" and "How do we teach implicit comparative law?" inform each other. Most obviously, since the focus of the course is as much on implicit as on explicit 
normative orders, a pedagogical approach emphasizing lectures that are meant simply to transmit information is unsuitable. Likewise, since unwritten norms and practices bulk large as objects of inquiry in this course, a pedagogical approach that aims only to compare formal institutions or contrast the written norms of different systems would be counter-productive. Further, being attentive to the assumptions of a critical legal pluralist hypothesis means ensuring that there is no single point of authority in the classroom. That is, to the extent that the course instructors alone take charge of each class, impose their conceptions of the subject and object of inquiry on other course participants, and control the scope of intellectual inquiry, they would be replicating in the classroom the monistic, top-down approach to legal norms that the course syllabus claims to reject.

To illustrate these points it is useful to return to the inventory financing example set out in the syllabus. The point here is that particular state legal systems and the more generic legal traditions they are believed to instantiate are not exhaustive of the comparative possibilities. In the inventory financing example, if we take the traditional comparative law approach comparing the regimes in Rouyn and Hawkesbury, we are reinforcing the orthodox view that the official "positive law" of the authoritative political regime is the primary normative system that governs commercial conduct among financers, wholesalers, retailers and customers.

But if, adopting a critical legal pluralist approach, we look at other normative regimes that might regulate this commercial conduct, the first inquiry would be: what are the different criteria by which we could aggregate particular instances? Consider what impact each of the following would have on our analysis of cognates or agnates: transaction type (financing wholesale distributions, financing retail sales); object of the transaction (snowmobiles, automobiles); overall economic structures (the economies of eastern North America, Europe, Australia); patterns of trade; affinities of corporate groups and dealerships; the types and roles of major lending institutions; local legal practices; the climate of labour relations; the possible uses of snowmobiles and automobiles; and 
so on. Equally relevant considerations for the navigation of the participating subjects' legal engagement and the competing legal orders governing their actions are considerations of the needs and wants of the parties to the transaction, the structure and status of their personal economies, the explanations and processes deployed during the negotiation process, and the mechanisms they prefer for dispute resolution.

The implicit comparative law hypothesis that we present recognizes and embraces this diversity. Indeed, our methodology means asking, in respect of the inventory financing example, under what social, economic and political conditions and under what conceptions of law would it be plausible to consider all the possible permutations and combinations of the eight geographic sites to be the most significant cognate grouping? This type of question, which we believe to be at the heart of the richest form of transsystemic teaching, is just the beginning. Until one actually begins to explore the official law governing a particular example comparatively, the myriad tacit normative regimes remain occult. As each tacit regime is revealed, we are in a position to assess the salience (or lack of salience) of the explicit criteria of comparison we may be presumptively adopting. In such an endeavour, we may discover, for the purposes of understanding the nature of regimes of inventory financing, that the primary cognate pairing of sites and regimes is snowmobiles in Geneva, Switzerland and automobiles in Toronto, Ontario, or snowmobiles in Thredbo, New South Wales, and automobiles in Paris, France. ${ }^{27}$

Of course, the example that we propose to invoke in the first session of our course should not be construed as suggesting that the implicit comparative law analysis requires, as its raw material,

27. For further development of these hypotheses see Roderick A. MACDONALD and Isabelle Deschamps, "Planimétrie et topographie en droit des sûretés " in Nathalie MARTIAL-BRAZ, Jean-François RifFARD and Martine BEHARTouchais (eds.), Les mutations de la norme, Paris, Economica, 2011, p. 117; and Roderick A. MACDONALD, "A Model Law on Secured Transactions. A Representation of Structure? An Object of Idealized Imitation? A Type, Template or Design? ", (2010) Uniform Law Review 419. 
units of comparison that are tied to, defined by, or, at the limit, even cognizable within, a political jurisdiction. In this initial session, we could easily have invoked interpersonal relationships as the orienting theme and drawn on the list of legal regimes governing the relationship between the co-authors of this paper as a source of comparative analysis. ${ }^{28}$ The commensurable units of all four quadrants of the matrix could be invoked, whether in a comparative analysis of the legal orders applicable to one relationship or as part of an inquiry into the normativity at stake in a range of interpersonal arrangements. The rationale for exploring this orienting inventory financing example is to illustrate that the design of any hypothetical fact situation offers an opportunity to explore the radically different regimes of comparison that are thrown up for analysis when an implicit comparative law methodology is deployed.

Given the inquiries that form the substance of this course, the appropriate pedagogical approaches set out in the syllabus are intrinsically constrained. A lecture method in which student interaction is minimal is not well conceived if a primary object is to encourage an active exploration of the tacit. The Socratic Method is also sub-optimal; for while a Socratic dialogue pushes students to revise and refine their initial responses to hypothetical problems posed by the instructor, there is usually little space left open for debating the premises that lie behind the problem chosen or the implicit limitations on the arguments from authority that can be made in support of the increasingly refined responses that are developed in response to instructor questioning. By contrast, methods that encourage all participants in the class to contribute to framing and reframing a problem, and which enable them to do so in diverse symbolic discourses that do not necessarily rest on the specificity of premises we associate with the logical syllogism, will lead participants to conceptions of the issue under discussion that, until the moment of discovery, were tacit. Finally, by requiring all course participants to take the lead in organizing at least one class

28. See section II.B, above. Patrick Glenn has developed a rich conception of the materials and objects of legal comparison that is consistent with this view of multiple normative orders in H. Patrick GLENN, "A Concept of Legal Tradition ", (2008) 34 Queen's L. J. 427. 
session, we hope students will learn the limits of discursive language in opening reflection beyond the realm of explicit normativity. ${ }^{29}$

\section{F. Assignments and Assessment}

This course attempts to integrate theoretical, methodological and substantive readings, resources and discussion with hands-on experience. The assessment scheme for the course reflects this objective. Several of its features are cardinal. First, the process will be continual throughout the semester. Second, the process will be both informal and formal. Third, the process will be interactive. Fourth, you will have a chance to tailor the evaluation process to your own needs and work with us in its specific design. In this regard, most assignments in this course can be submitted in alternative linguistic formats - poetry, plays, and short stories - and in nontextual forms of symbolic discourse - visual arts, music, drama, dance, mime, film - or a combination of these forms and modes. You may simply assume that your assignments may be submitted in any format that we have adopted as a mode of communication in our classroom teaching.

You will be assessed on the basis of four sets of exercises. Some of these will be graded on a pass/fail scale, while others will be evaluated according to the Faculty's letter-based calibration. Moreover, the evaluation of your assignments will sometimes be undertaken by the instructors, sometimes by your peers, and sometimes by you on the basis of your own criteria (self-evaluation). Some parts of each exercise are to be undertaken individually and other parts, in groups. To the latter end, at the beginning of the term, you will form yourselves into teams of five or six. Your team will serve not only as a locus for several parts of the assessment process during the semester, but also as one of your primary normative orders and sites for comparative evaluation in the course.

29. Roderick A. MACDONALD, "Everyday Lessons of Law Teaching - Le quotidien de l'enseignement juridique ", (2012) Canadian Legal Education Annual Review 1. 
The first series of exercises consists of the following activities:

$$
\text { Classroom participation - Pass-Fail }
$$

You will be expected to engage thoughtfully in each course session by: (1) attending class (individual); (2) preparing for class, both by addressing a query specifically assigned to you (individual) and by considering from a comparative perspective the taxonomic criteria that each member of your group has deployed to address the question (group); (3) posting comments online (both before and after class) on themes being discussed (individual or group, at your option). You are free to select the mode and manner of your classroom participation, which may involve a variety of expressive forms.

(2) Field trip - Pass-Fail

During the semester, we expect each of you to undertake two field trips to sites where you can observe multiple normative orders in interaction. One field trip will be undertaken on your own, the other with your group. You will be expected to share your field trip experiences with other members of the course by posting an account on the relevant online course discussion board. Your posted comments should pay particular attention to the implicit dimensions of the normative interactions you observe.

The second set of exercises has two parts:

$$
\text { Teaching one seminar session - 33\% }
$$

Each group will be responsible for preparing and leading one class session over the course of the term. This exercise involves five distinct steps: (1) Selecting preparatory materials; (2) Designing a lesson plan; (3) Leading a class session; (4) Meeting with us and the designated peer evaluators for a de-brief of your class; and (5) Submitting a brief group report detailing your pedagogical choices and an individual self-evaluation of the session. 
Each student will act as a commentator for a session taught by another group. Peer evaluators will be responsible for providing individualized written feedback to the session leaders. In addition, there will be a formal peer review session with the session leaders, peer evaluators and course instructors.

The third set of exercises (33\% of your final grade) concerns the normativity that structures the functioning and inter-personal interaction between members of your group. At the beginning of the course, your group will record the explicit rules that govern your intragroup interactions. At the end of the course, you are expected to report on the normative order you have created, and its relationship to other normative orders that make claims on you in connection with this course, developing the comparative dimensions of these orders. You should undertake this report in collaboration with your group.

The fourth set of exercises (33\% of your final grade), to be undertaken individually, is to design and elaborate your own law faculty course entitled "Implicit Comparative Law". This course might be an explicit instantiation of the personal learning syllabus that you have been formulating (consciously and unconsciously) throughout the semester. Alternatively, you might imagine some other form of implicit comparative law course on offer in a law faculty, another University unit, a CEGEP, a high school, an elementary school, as part of a public legal education programme, or as part of a professional primary, continuing or training education programme. You are expected to prepare all the materials that are associated with designing a course of the type or form you have selected (i.e. a brief course description suitable for a public announcement, a course syllabus, a reading list, evaluation materials and a grading scheme, a detailed description of the course content and pedagogical approach for one class session, and any additional foundational materials associated with the design of your particular course) and a comprehensive text explaining your pedagogical choices. 


\section{Commentary:}

Evaluation, in its many forms and whatever its objectives and modalities, is a familiar feature of any course. However the learning objectives of a course may be framed, professors and students confront the question: So what? What have we learned? And however these questions are answered, we face its corollaries: How do you know? How can we assess what has, or has not been learned? These latter queries raise especially vexing inquiries when the focus of the course under examination is on the implicit dimensions of law and legal ordering. This is because in any pedagogical endeavour, one would expect that the hypotheses about law that the course proposes and the processes of discovery and learning that the course aims to compel are reflected in the evaluation processes - that is, in the course assignments and the manner of assessment.

It might initially be thought that the section of a syllabus devoted to assignments and assessment would not be a significant part of our course on Implicit Comparative Law. There are, however, two reasons why we have devoted so much attention to assessment. First, given our approach to pedagogy it is impossible to distinguish between features of the course that aim at teaching, and features that aim at assessment. In the formative evaluation approach, assessment and feedback are a central part of the pedagogy, and deserve as much attention as classroom sessions and other activities. Second, the course is about "implicit" comparative law. Consistently with that ambition, we conceive much of the learning of the course to take place implicitly. Assessments and evaluations do not look like exercises of discovery of comparative law, but if they are properly crafted they are reflections of the analytical substance of the approach we take to this course. That is, it is the parts of the course that do not explicitly present themselves as being about implicit comparative law where the lessons of implicit comparative law are most richly revealed. 
In our proposed course, many assessments involve formal exercises requiring the submission of written material. At first glance, it would seem that such evaluation methods cannot be squared with a pedagogy that focuses on the theory and practices of implicit comparative law. However, this would be to misinterpret the iterative orientation of all course assignments. Like our understanding of comparative endeavours and of law, we understand teaching and learning and, concomitantly, the methods and goals of evaluation, to be fluid, narrative, individual and group based, formal and informal, and - most importantly - self-reflexive. Teaching and learning implicit comparative law requires inquiry into human interaction, human purposes and the diverse normative modes and sites within which human agency is pursued. The multi-faceted evaluation process we have proposed seeks to accommodate and replicate the assumptions and pedagogical practices of the course itself.

Given our parameters and presumptions about law and about assessment, it is obvious that a sit-down final examination would not be an appropriate mode of evaluation for this course. Such an exercise is fundamentally summative (a snapshot verification of how much specific information has been internalized and what specific skills have been mastered). It is neither formative (a further step in the process of discovery and learning that will be complemented by extensive feedback leading to additional learning opportunities) nor motivational (it does not provide the occasion for student-initiated interactive learning). Moreover, given our position that the sites and modes of law - and thus of comparative law - are boundless, it makes sense that the evaluation components for this course require course participants to reflect on what they are learning about law both individually and collectively and both inside and outside the classroom. It, further, makes sense that the evaluative framework we have constructed is ongoing throughout the course and is as concerned with means (how am I learning) as with ends (what am I learning). This is why most of the ungraded exercises are meant to have students examine and critique their own pedagogical practices, and their own learning mechanisms, as 
well as to assess these practices and mechanisms in comparison with those proposed by their classmates.

In such a conception of assessment, there is no sharp distinction between learning and evaluation. Participating in a field trip, writing a diary or log of the course that will form part of an end-of-semester report, assessing not only the materials course instructors have prepared for individual seminars, but the actual performance of the seminar itself, and designing a specific implicit comparative law course on a topic of interest are each occasions for students to engage with legal comparison in multiple symbolic registers. Consistent with the tenets of the critical legal pluralist hypothesis animating this course and with our invitation for students to engage with law in its multiple contexts, we encourage students to submit their various assignments either in nontraditional textual formats or in non-textual formats.

Finally, each of the assignments has been crafted so that students have considerable latitude in imagining the starting points and objects for their submissions. We hope that most assignments will have a strong element of self-reflexivity. For example, a student might design a syllabus for an implicit comparative law course around a comparative law conference programme: what topics were included? what topics were not discussed? what theories of comparison were adopted by different authors? In every instance, the assignment will require students not just to address questions such as those just posed, but also to explain what alternatives they had contemplated and why these alternatives were rejected.

Here is another example of how reflexivity could be demonstrated in a written assignment. A student might consider writing a field trip report about attendance at the 50th Anniversary Conference of the Quebec Society of Comparative Law. In such a report, what might be particularly interesting would be a report or commentary that also examined the already mentioned transformation of the Society's name. What epistemological and ontological assumptions about the very idea of comparison in law can be seen in the substitution of the name "Quebec Society of 
Comparative Law" for the initial name "Quebec Association for the Comparative Study of Law"? and were any of those assumptions explicit in the thinking of those who proposed and supported the change? Such a report could then go on to consider possible future name changes for the Society - perhaps to the "Quebec Society for the Study of Approaches to Implicit Comparative Law" or the "Quebec Society for the Comparative Study of Implicit Law" or, perhaps even more appropriate, the "Quebec Society for the Comparative Study of Legal Epistemologies". Preparing such a report would require the student to embark upon and map an intellectual journey akin to the individual journeys that we chronicled in the Synopsis and Rationale section of the syllabus. ${ }^{30}$

\section{G. Feedback}

Underlying the notion of implicit comparative law developed in this course are several assumptions about law inherent in the critical legal pluralist hypothesis. To recall, law is conceived as (1) interactional, (2) polycentric, (3) facilitative, and (4) not exclusively chirographic. In keeping with these premises, the feedback mechanisms in this course are meant to offer opportunities for all participants - as teachers and students - to contribute to each other's learning. Accordingly, we institutionalize several channels of communication among course participants, while also recognizing that informal feedback is inevitable, fruitful and most reflective of the second-order objectives and learning outcomes outlined earlier.

Most obviously, feedback among course participants is a mechanism for assessing how well the course objectives are being attained. Formal feedback by way of questionnaire is especially helpful for making specific adjustments to improve the course on the

30. The exercise of contrasting assumptions that are carried by different arrangements of the words in a title applies as much to the title of this course as it does to the name of the association that sponsored the conference at which this essay was presented. For example, students could be invited to write a report comparing the assumptions that would change were this course entitled "Comparative Implicit Law" rather than "Implicit Comparative Law". 
fly and for reimagining its components for future years. Informal, unstructured feedback complements these goals and also tends to identify unintended or unexpected learning outcomes and to generate unusual and innovative proposals concerning both substantive objectives and pedagogical strategies. But feedback is not simply about measuring achievement. The endeavour of providing feedback is itself a teaching-learning opportunity. Peer evaluation by students (by ricochet) and self-evaluation (directly) engage course participants in the central intellectual processes of comparison and self-reflection.

\section{(1) Our feedback to you}

We will provide you with ongoing feedback on all aspects of your performance in this course, including written comments on each assessment. The evaluation criteria, posted on the website, will orient our comments. Also, we invite you to propose to us your own criteria by which you would like us to assess your performance. In addition to our willingness to discuss the course and your concerns in informal settings like Coffee House, we also undertake to respond promptly to e-mails and to postings on discussion boards on the course webpage. We are available during our office hours, by appointment and before/after class to discuss the course and your performance and progress in it. In keeping with the interactive character of the course, on several occasions during the semester, we will also be posting on the website our self-evaluation of our own contributions.

\section{(2) Your feedback to us}

We welcome your feedback about all aspects of this course. If warranted by the size of enrollment, we will create a class committee to meet with us every three weeks to review any matter relating to the course. In either the presence or absence of such a committee, you are encouraged to communicate with us about the course at any time by speaking with us after class, contacting us by phone or email, submitting comments via the anonymous feedback forms (available on the course website), posting comments on the course website, or completing a formal evaluation during the course evaluation period. 


\section{(3) Your feedback to each other (peer evaluation)}

As you know from the modes of assessment, you are each expected to evaluate a class session taught by a group of your classmates. The class discussion board and other tools on the website also provide opportunities for you to give formal feedback to each other during the course of the semester. Finally, and once again in keeping with the informal aspects of the course, you should be aware that the manner of your interaction through everyday classroom participation is a powerful implicit feedback mechanism that can be deployed to contribute to your own learning, as well as that of your classmates.

\section{(4) Your feedback to yourselves (self-evaluation)}

Part of two course assignments - the teaching of a class and the design of your own course - involve you submitting a selfevaluation of your performance. In addition to these formal occasions for you to reflect on your participation in and contribution to the learning of others in the course, we hope that you will keep an informal diary to track your reactions to individual classes, to assigned materials and to the engagement of other course participants. In section $C$ of this syllabus - Specific Learning Outcomes - we signal that the course is meant to be self-reflexive. Your continual self-evaluation, making use of the entire range of explicit and implicit normative resources canvassed in the course, is the most important vehicle you have for assessing how well you are coming to understand the diverse possibilities for learning law that are opened up by the implicit comparative law hypothesis.

$$
* * * * *
$$

\section{Commentary:}

In any course, timely and thoughtful feedback among the participants is crucial to achieving the course objectives. In important respects, evaluation is personal and is conditioned by how well or how poorly other course participants are performing. 
Ultimately, however, assessment and feedback in formal education settings are comparative exercises; course instructors are required to assess and report on performance and progress according to some formal criteria and to differentiate and group students, usually on a pass-fail basis, or by means of numerical letter grades.

As with the section of the syllabus devoted to assignments and assessment, it might be thought that the section on feedback has little to do with the substance of a course on Implicit Comparative Law. But because our theoretical approach is critical legal pluralism, in which everyone is a law-creating agent, the occasions for feedback are central moments in the development of the normative regime that governs the relationship among course participants. Moreover, how each student constructs and navigates this regime is an important site for comparative analysis. Such analysis is multi-dimensional, but we seek to encourage two types of comparative reflection in particular. First is the exercise of situating one's own construction of the normative regime in relation to that of others. What are the modes and mechanisms of interaction between these regimes and the individuals and norms within them? Second is the exercise of situating one's own construction of the present normative regime in relation to those of the past and of the future. How do the multiple instantiations of self at one particular time and over time contribute to norm creation, interaction and change? For these reasons we feel it is important to provide a detailed exposition of how different forms of feedback serve as modes and sites through which these individual legal systems are configured, experienced and communicated by members of the seminar.

In other words, in this course we attempt to align our processes of feedback with our processes of assessment, and to structure both so as to reinforce the course objectives. For example, evaluations are conceived primarily as a mode of providing feedback. The character and quality of student assignments provides feedback to instructors, just as commentary on submitted work provides feedback to students. The exercises of evaluation and feedback inevitably host a comparative dimension, as all 
participants necessarily locate themselves by reference to the performance of others. As instructors, we therefore need criteria of aggregation and differentiation that permit us to tailor feedback to the assignment and to the student submitting the assignment. That said, feedback from multiple evaluators is never identical, either in its reference points, in its modes of expression, in its degree of explicitness or in its commitment to the instrumental triptych of objective, performance, assessment.

Accordingly, both the explicit and implicit feedback mechanisms that are embedded in our syllabus reflect the multidimensional quality of the instructor-student relationship. Not only are the sites of feedback multiple, the symbolic form in which feedback is provided and the purposes and features of providing feedback are multiple. Indeed, if all feedback is comparative, informal feedback that does not even announce itself as such instantiates the same types of implicit comparison that are present in the everyday pedagogy of the course.

Finally, the cumulative effect of the exchange of feedback between instructor and students and among students themselves becomes an exercise in comparative law. Participants must ask, "On what basis can the criteria, forms and character of feedback be compared?" And, having posed this question, they must then compare how these messages of the unofficial and implicit feedback vehicles either reinforce or differ from those transmitted by the course's official and explicit feedback mechanisms.

\section{H. Week-by-Week Outline of Seminar Sessions}

\section{Week 1 Introduction}

\section{Part One: Introduction to Comparative Law}

Week 2 Identity, comparison, commensurability

Week $3 \quad K n o w l e d g e$, language, communication

Week 4 What law? Critical legal pluralism 
Week 5 What comparison? Implicit and inferential legal normativity

\section{Part Two: Case Studies - Sites of Comparative Legal Analysis}

Week 6 Legal orders, legal systems, legal families, legal traditions

Week 7 Legal institutions for making, administering and applying law

Week 8 Legal doctrine-norms, concepts, procedures

Week 9 Legal education - is and ought in legal comparison

\section{Part Three: Case Studies - Modes of Comparative Legal Analysis}

Week 10 Endogenous (conceptual) legal comparison

Week 11 Exogenous (functional) legal comparison

Week 12 Inputs - Temporal legal comparison

Week 13 Outputs - Harmonization, transplants and viral

Week 14 Conclusion

\section{CONCLUSION}

A course syllabus is always aspirational. In its explicit presentation, it erects the scaffolding on which a course is constructed and reconstructed by the course participants as scholastic terms unfold. In its implicit and inferential dimensions, a syllabus aims to propel a course forward without constraining the participants' experiences, learning processes and outcomes. Explicit in the syllabus for our particular instantiation of an implicit comparative law course is the proposition that re-imagining comparative law as implicit comparative law entails a taxonomic shift and a multiplication of potential comparative units. New categories of comparison emerge, along with new sites of comparative inquiry, and new modes, schema and distributions of comparison. But, as is also explicit in the articulation and design of our course, much more significant than the magnification and 
multiplication of comparative quantity are the hermeneutic and qualitative shifts that implicit comparative law entails. The metashift disrupts the meaning and presence of comparative law (existential), the sources of legal and comparative knowledge (epistemological) and the sites, processes and outcomes of comparison (ontological).

Traditional comparative law has often seemed to assume that a single homogenous legal order defines a legal territory and that that defining legal order (and its homogeneity) are commensurable with the defining orders of other political territories. ${ }^{31}$ It is true that when we contemplate, theorize, teach and write the law, we (most often implicitly) privilege a particular location - species, genus, order, family. It is also true that when we contemplate, theorize, teach and write the law, we make (most often implicitly) substantive choices about our organizing frames: sometimes these frames are sites of law (the courtroom, the battlefield, the highway, the home or legal families, traditions or system); sometimes modes of legal expression (statute, conversation, case law, contract); sometimes disciplinary extroversions that police the boundaries of inquiry (securities law, intellectual property, comparative law). When our intellectual endeavours in law announce themselves as being comparative, these privileging choices are more explicit. ${ }^{32}$ However,

31. This is not to say that the law in action is ignored; the claim, rather, is that outcomes are always predicated on a reference to formal law. Compare the analysis in Christopher A. Wнутоск, "Legal Origins, Functionalism, and the Future of Comparative Law ", (2009) 6 Brigham Young University Law Review 1879.

32. For example, in the Glennian tradition the rubric of "legal tradition" offers a way of situating the varying global meanings and roles of Law and laws as part of "the changing presence of the past": H. Patrick GLENN, Legal Traditions of the World: Sustainable Diversity in Law, 4th ed., New York, Oxford University Press, 2010, p. 22. Glenn offers the following list of legal traditions: Chthonic, Talmudic, Civil, Islamic, Common, Hindu, and Asian. For another definition of "legal tradition" (that is, as "set of deeply rooted, historically conditioned attitudes about the nature of law, about the role of law in the society and the polity, about the way law is or should be made, applied, studied, perfected, and taught .... [that] puts the legal system into cultural perspective"), see John Henry MERRYMAN and Rogelio Pérez-Perdomo, The Civil Law Tradition, 3rd ed., Palo Alto, Stanford 
whether explicit or implicit, intentional or unconscious, the privileging choices almost always disclose a presumption that at some relatively low level of abstraction, differences are commensurable. That is, the common view seems to be that abstraction can reveal a common lexicon in which particular differences can be noticed, measured, evaluated and learned from.

All abstractions are intended to regroup and differentiate. However, at some level of abstraction, distinctions between units of comparison disappear from view. In physical terms, the notion is captured by the zoom out function on GoogleMaps, which, with increased retraction from Earth, homogenizes the indicators of human life and differentiation into large-scale blends of topographical features. ${ }^{33}$ The lesson of implicit comparative law is,

University Press, 2007, p. 2. Alternatively, David and Brierley posit "legal family" as the criterion of classification, with designations assigned on the basis of the ease of cognitive mobility between jurisdictions and the absence of diverging foundational propositions: René DAVID and John E.C. BRIERLEY, Major Legal Systems in the World Today: An Introduction to the Comparative Study of Law, 3rd ed., London, Stevens \& Sons Ltd, 1985, p. 12. David and Brierley identify the following major contemporary families of law: Romano-Germanic, the common law, socialist laws, and philosophical or religious systems.

33. If we plot a location on a GoogleMap, we can zoom in to view that location at a level replicating physical presence. From this perspective, the distinctions between buildings, bricks, license plates and advertisements are discernible, easily so. Indeed, these distinctions remain in focus - and may even sharpen - as we slowly zoom out. However, beyond a certain point, each click of the "zoom out" button blurs sharp distinctions. As the view pulls back from the Earth, streets, airports and trees blend into abstract configurations of gray and green. Continued zooming out blends boundaries further, creating a topography of urban spaces juxtaposed with apparently uninhabited areas of varying elevations and forestation levels. Ultimately, only the distinctions between land and water, snow and forest remain. We find an analogous example of the blurring of distinctions in the conceptual foundations of Christianity. According to this tradition, the sins of and distinctions between particular individuals disappear in the presence of God, that is, the insurmountable imperfection of human finitude becomes immanent and collective in the presence of God's infinite perfection: see e.g. "The Rev. Dr. Boynton's Prayer " in Christopher L. WeBBer (ed.), An American Prayer Book, Harrisburg, Morehouse Publishing, 2008, p. 80. In yet a different context, Oliver 
however, not that distinctions vanish in the presence of the infinite. We learn, rather, that whenever and wherever we perform aggregations, we make choices. Because of the analytical rigour that taxonomy purchases, we often fail to acknowledge the contingency of these choices, and the politics they reflect. ${ }^{34}$ Indeed, these choices often seem like natural or optimal ones, but ultimately - indeed, fundamentally - these choices are neither necessary nor ideal. Rather, the lines we draw in our decisionmaking and choice-selection efforts are grounded in deliberation and purpose. In other words, all intermediate distinctions between conceptions of infinity - are products of judgment.

In recognition of these exercises of personal volition and circumspection, implicit in our syllabus is the unstated hope that, by the end of our Implicit Comparative Law course, students will have come to the realization that privileged choices at the level of abstraction are arbitrary (that is, discretionary) but not capricious (that is, not careless or whimsical). ${ }^{35}$ The aim of implicit

Wendell Holmes noted the effect of abstraction on difference by using mathematical theory as a simile for certain realms of jurisprudence. "I do not say", he wrote, "that there is not a wider point of view from which the distinction between law and morals becomes of secondary or no importance, as all mathematical distinctions vanish in the presence of the infinite": Oliver Wendell Holmes, Jr., "The Path of Law ", (1897) 10 Harvard L. Rev. 457, p. 459. Holmes was of the view that the distinction was important to the "right study and mastery of the law as a business with well understood limits, a body of dogma enclosed within definite lines".

34. R. A. MACDONALD, "Is Law a Zoo? ", supra, note 2.

35. "All normative regimes are radically heterogeneous in every artefactual ambitions. Moreover, all normative regimes are in constant flux; over time not only their institutional, methodological, procedural and substantive content, but even their basic orientations seem to mutate. Given the complexity of modern western societies, the political attempt to eliminate (and the intellectual attempt to reconcile) normative dissonance - be it within any normative order, or across normative orders - would be futile. To model consonance is an instrumental goal requiring conscious effort that already implies a privileging of a particular archetype of legal normativity and a particular conception of a normative regime": R. A. MACDONALD, "Critical legal Pluralism as a Construction of Normativity and the Emergence of Law ", supra, note 24. 
comparative law is to change both the scale and the register of judgment in the comparative analysis. The ultimate reductio on an implicit comparative law approach is not infinity, but rather the individual - for that human being is not just the subject of law, but in each of the multiple normative regimes that compete for loyalty and adherence, is also law-maker and law-applier. Individuals invoke comparison - whether implicitly or explicitly, exclusively or in tandem with other modalities, superficially or reflexively - as a strategy for structuring their categories of knowledge and understanding their place in the world. It is, at bottom, a strategy that presupposes an exercise of distinguishing self from other. Implicit comparative law aspires to empower individuals to make the choices that they consider compelling and to conceive of the other in a way that is personally meaningful, whether that be tied to the law of another state or legal tradition, the local law, the law of organizations, transnational law, or the law of the everyday.

\section{Appendix: Annotated Bibliography}

No course will ever be complete in its own terms. It will always open doors to that which lies beyond the formal tuition. The written syllabus to which this Appendix is attached is, at best, the formulaic expression of the pedagogical content of the course. Classroom sessions will take us into the realm of the interactional and the inferential. At such a point, the course becomes an invitation to further inquiry and reflection. To assist you in this endeavor, we have prepared a general bibliography of works that take up themes suggested in this course. It should be read as a whole, as the sources cited under one heading often implicate a range of relevant material. 36

\section{The Foundations of Comparative Legal Knowledge}

$$
\begin{gathered}
\text { Comparison is a mechanism of social navigation, } \\
\text { communication, evaluation and interaction; it offers a way of }
\end{gathered}
$$

36. The use of italics in the presentation of this Appendix indicates (correctly) that the Annotated Bibliography contained therein attaches to our course syllabus. Indeed, the Annotated Bibliography is our attempt to offer our 
knowing (epistemology), an aspect of being (ontology), a vehicle for meaning (semantics) and an education in virtue (ethics); it is a fundamental reflex of the human species. Moreover, comparative methods, theories and analyses have become mainstays of legal study. The seminal texts of $20^{\text {th }}$ century North American and Western European comparative law are multiple and their staying power is manifest. See: Rudolph SCHLESINGER, Comparative Law: Cases and Materials, Brooklyn, Foundation Press, 1950 (the $7^{\text {th }}$ edition Schlesinger's Comparative Law - authored by Ugo Mattei, Teemu Ruskola and Antonio Gidi, was published in 2009); Arthur VON MEHREN, The Civil Law System: Cases and Materials for the Comparative Study of Law, Englewood Cliffs, NJ, Prentice-Hall, 1957 (the $2^{\text {nd }}$ edition - The Civil Law System: An Introduction to the Comparative Study of Law - written with James R. Gordley was published in Boston by Little Brown \& Co in 1977); René DAVID, Les grands systèmes de droit contemporains, Paris, Dalloz, 1964 (the $11^{\text {th }}$ edition, with Camille JAUFFRET-SPINOSI, was published in 2002)

students a survey of the sources that facilitated the design and construction of the course and of materials through which they can undertake a more searching inquiry into and beyond the formal and obligatory course coverage. Our intentions for the Annotated Bibliography are, however, not exclusively bound to the tuition of our proposed course. Rather, the Annotated Bibliography attaches simultaneously to the course syllabus and to this paper as a whole. Accordingly, it not only charts a path for students, but also symbolizes our own (past, present and future) route to an idea of implicit comparative law. For the most thorough account of the sources paving that route, the Annotated Bibliography should be read in conjunction with the Primary Reference Materials section of the syllabus (II.D) and the footnotes attached to the Commentary portions of this paper. That said, such a reading should not be interpreted as a claim that students in the seminar should replicate the intellectual journey laid out in the Primary Reference Materials and the Annotated Bibliography. A claim of that order misunderstands the nature and objectives of the course. Rather, recall our assumption that students will critically engage with and assess the obligatory and primary reference materials set out in the syllabus (II.D). In conjunction, we expect students in the seminar to interrogate the substance and form of the Annotated Bibliography itself, as well as the sources listed in it, to determine whether the organization of knowledge and assumptions they embody comport with their own understanding and practice of implicit comparative law, and to formulate a compilation of sources that best symbolizes their own individual journey. 
(see also the English version, René DAVID and John E.C. BRIERLEY, Major Legal Systems in the World Today: An Introduction to the Comparative Study of Law, London, Steven \& Sons, 1968 (the 3rd edition was published in 1985)); John Henry MERRYMAN, The Civil Law Tradition: An Introduction to the Legal Systems of Western Europe and Latin America, Stanford, CA, Stanford University Press, 1969 (the $3^{\text {rd }}$ edition was published in 2007); Konrad ZWEIGERT and Hein KOTZ, Introduction to Comparative Law, Amsterdam, North Holland Publishing Co., 1977 (the $3^{\text {rd }}$ revised edition was published by Clarendon Press in 1998); Peter DECRUZ, Comparative Law in a Changing World, London, Cavendish, 1995 (the $3^{\text {rd }}$ edition was published in 2007); H. Patrick GLENN, Legal Traditions of the World: Sustainable Diversity in Law, New York, Oxford University Press, 2000 (the $4^{\text {th }}$ edition was published in 2010).

A range of additional perspectives that stand as prominent contributions to the development of comparative legal thought are found in the following works: Bronislaw MALINOWSKI, Crime and Custom in a Savage Society, Paterson, NJ, Littlefield Adams, 1926; John Henry WIGMORE, A Panorama of the World's Legal Systems, Saint Paul, West Publishing Co., 1928; Max RHEInsteIn, "Teaching Comparative Law", (1938) 5 U. Chicago L. Rev. 615; Marc ANCEL, Utilité et méthodes de droit comparé, Éléments d'introduction générale à l'étude comparative des droits, Neuchâtel, Éditions Ides et calends, 1971; Max RHEINSTEIN, "The Family and the Law", in Max RHEINSTEIN (ed.), International Encyclopedia of Comparative Law, vol. IV, Persons and Family, Paris, Mohr, 1973; Rodolfo SACCO, La comparison juridique au service de la connaissance de droit, Paris, Economica, 1991; Calum CARMICHAEL (ed.), Collected Works of David Daube, 4 vols., Berkeley, University of California, 1992; Pierre LEGRAND and Roderick MUNDAY (eds.), Comparative Legal Studies: Traditions and Transitions, Cambridge, Cambridge University Press, 2003; Roger COTTERRELL, Law, Culture and Society, Aldershot, Ashgate, 2006; and Gilles Cuniberti, Grands systèmes de droit contemporains, $2^{\text {nd }}$ ed., Paris, L.G.D.J., 2011.

In embarking on a re-imagination of the meta-hypotheses of comparative law, we take a cue from observations of comparative 
law's "identity crisis" and other indications of uncertainty and dissatisfaction within the field: John W. HEAD, Great Legal Traditions: Civil Law, Common Law, and Chinese Law in Historical and Operational Perspective, Durham, NC, Carolina Academic Press, 2011; Esin ÖRÜCÜ and David NELKEN (eds.), Comparative Law: A Handbook, Oxford, Hart Publishing, 2007, especially the contributions by Örücü, Twining, and Menski; Esin ÖRÜCÜ, The Enigma of Comparative Law: Variations on a Theme for the Twentyfirst Century, Leiden, Martinus Nijhoff, 2004; Bernhard GROSSFELD, Core Questions of Comparative Law, Durham, NC, Carolina Academic Press, 2005, translated by Vivian Grosswalk Curran; Jerome HALL, Comparative Law and Society Theory, Baton Rouge, Louisiana State University Press, 1963; Maurice ADAMS, "Doing What Doesn't Come Naturally. On the Distinctiveness of Comparative Law" in Mark VAN HOECKE (ed.), Methodologies of Legal Research: Which Kind of Method for What Kind of Discipline?, Oxford, Hart Publishing, 2011, p. 229; David S. CLARK, "Comparative Legal Systems" in David Scott CLARK (ed.), Encyclopedia of Law and Society: American and Global Perspectives, Thousand Oaks, CA, SAGE, 2007, p. 224; Annelise RILES, ed., Rethinking the Masters of Comparative Law, Oxford, Hart Publishing, 2001; Edward EBERLE, "The Method and Role of Comparative Law", (2009) 8 Washington University Global Studies Law Review 451.

\section{The Pedagogy of Comparative Law}

The theory of transsystemic teaching embodied by the McGill Programme provides that private law courses are taught without a "pedigree designation" as civil or common. As Professor Shauna Van Praagh explains in her preface to the McGill Law Journal's special issue, "Navigating the Transsystemic", (2005) 50 McGill L.J. 701ff, understanding the McGill Programme entails active reflection on relationships, in particular, relationships between norms and sources; between law, culture, philosophy and time; between normative orders, traditions, approaches and practices; and between individuals, aspirations and social transformation. For more searching and particularized explorations of the theory and practice of McGill's transsystemic programme, see: 
(a) with respect to the epistemic and conceptual shifts at stake in a transsystemic approach: Roderick A. MACDONALD and Jason MACLEAN, "No Toilets in Park", above, II.D (a shift to "constitutive polyjurality", a term symbolizing the unification of a transformation from mono or bi-jurality to polyjurality and a revitalization of the constitutive ambition); H. Patrick GLENN, "Doin' the Transsystemic: Legal Systems and Legal Traditions", (2005) 50 McGill L.J. 863 (a shift beyond the systemic to where the normative action is, namely, the legal tradition); Richard JANDA, "Toward Cosmopolitan Law". (2005) 50 McGill L.J. 967 (a shift from law to cosmopolitan law, and from a universal law of hospitality to a hospitality among plural legal orders);

(b) in relation to mapping the implications of a pluralist conception of law for the normative experience: Jacques $P$. VANDERLINDEN, "Une lecture du système normatif de l'Église catholique par un pluraliste comparatiste aux personnalités multiples", above, II.D (by asking whether canon law is law or theology); Emmanuel MELISSARIS, "The Chronology of the Legal", (2005) 50 McGill L.J. 839 (by exploring the "chronos" of law); and Etienne LE ROY, "Bricolages anthropologiques pour promouvoir, en Afrique et ailleurs, un dialogue entre univers juridiques "(2005) 50 McGill L.J. 951 (by investigating the cultural dimensions of juridicity);

(c) in relation to articulating the experience and aspiration of transsystemia "on the ground": Rosalie JUKIER, "Where Law and Pedagogy Meet in the Transsystemic Contracts Classroom", (2005) 50 McGill L.J. 789 (using the example of specific performance as reflecting the transsystemic move from the sequential to the integrated and from perspectives to legal traditions) and Susan DRUMMOND, "Prolegomenon to a Pedestrian Cartography of Mixed Legal Jurisdictions: The Case of Israel/Palestine", (2005) 50 McGill L.J. 899 (reconceptualizing what mixed legal jurisdictions are by looking to the example of Israel and Palestine);

(d) with respect the confrontation between institutional maturation and practical challenges: Harry ARTHURS, "Madly off in 
One Direction: McGill's New Integrated, Polyjural, Transsystemic Law Programme", above, II.D; and

(e) in relation to the human agency required to navigate the transsystemic: Shauna VAN PRAAGH, "Preface", (2005) 50 McGill L.J. 701 and Thomas R. BERGER, "One Man's Justice: My Life in the Courts" (2005) 50 McGill L.J. 987.

\section{Course Objectives}

\section{Objective One: Beyond explicit, formal law}

Human interaction is fundamentally plural. The four-cell matrix presented in this syllabus is one way to symbolize the diversity, heterogeneity and complexity of the normativity of human interaction. Detailed elaborations of the matrix model are found in Roderick A. MACDONALD, "Vers la reconnaissance d'une normativité implicite et inférentille", (1986) XVIII Sociologie et Sociétés 48 and Roderick A. MACDONALD, "Les vieilles gardes: hypothèses sur l'émergence des normes, l'internormativité et le désordre à travers une typologie des institutions normatives " in Jean-Guy BELLEY (ed.), Le droit soluble: Contributions québécoises à l'étude de l'internormativité, Paris, Librarie générale de droit et de jurisprudence, 1996, p. 233. Diagrams of the contemplated matrix can be found at page 53 of the former essay and page 246 of the latter. To explore the distinction between diagonally opposite quadrants of the matrix and the spectrum of phenomena that the matrix can accommodate, compare traditional conceptions of manifest legal phenomena with the fridge door statute (latent) detailed in Roderick A. MACDONALD, "The Fridge-Door Statute", (2001) 47 McGill L.J. 11.

\section{Objective Two: Beyond State Legal Positivism}

Contemporary scholarship on pluralist approaches and understandings of law is extensive. The literature spans the doctrinal to the social scientific to the critical. For an introduction to a range of pluralist perspectives, compare the essays of Lon Fuller collected in 
K. WINSTON (ed.), The Principles of Social Order: Selected Essays of Lon L Fuller, Revised Edition, Durham, Duke University Press, 2002; John GRIFFITHS, "What is Legal Pluralism?", (1986) 24 J. of Legal Pluralism 1; Sally ENGLE MERRY, "Legal Pluralism", (1988) 22 Law \& Society Review 869; Brian Z. TAMANAHA, "The Folly of the 'Social Scientific' Conception of Legal Pluralism" (1993) 20 J. L. \& Soc'y 192; Brian Z. TAMANAHA, "A Non-Essentialist Version of Legal Pluralism", (2000) 27 J. Law \& Soc'y 296; E. MELISSARIS, "The More the Merrier? A New Take on Legal Pluralism", (2004) 13 Soc. \& Legal Stud. 57; and Daniel JUTRAS, "The Legal Dimensions of Everyday Life", (2001) 16 C.J.L.S. 65. For taxonomic analyses and critique of the multiple versions of the legal pluralist hypothesis, see KLEINHANS and MACDONALD, above, II.D and MACDONALD, "Here, There... and Everywhere: Theorizing Legal Pluralism; Theorizing Jacques Vanderlinden", above, II.D.

\section{Objective Three: Beyond individuals as external legal objects}

The key sources on the theoretical origins of critical legal pluralism are listed in the Primary Reference Materials section of this syllabus. For a sample of integrated and intricate contributions to the projects of critical legal pluralism and of overcoming the "isms" of Anglo-American state legal positivism, see:

(a) in respect of everyday life: Roderick A. MACDONALD, Lessons of Everyday Law, Montreal, McGill-Queen's Press, 2002;

(b) in respect of issues of governance and law-making: Roderick A. MACDONALD, "Unitary Law Re-form, Pluralistic Law ReSubstance: Iluminating Legal Change", (2007) La. L. Rev. 1113 ; Roderick A. MACDONALD, "Triangulating Social Law Reform" in Ysolde GENDREAU (ed.), Dessiner la société par le droit/Mapping Society Through Law, Montreal, Éditions Thémis, 2004, p. 117; Roderick A. MACDONALD, "Legislation and Governance" in Willem WITTEVEEN and Wibren VAN DER BURG (eds.), Rediscovering Fuller: Essays on Implicit Law and Institutional Design, Amsterdam, Amsterdam University Press, 1999, p. 279; 
(c) in relation to identity and multiculturalism: Roderick $A$. MACDONALD, "Legal Republicanism and Legal Pluralism: Two Takes on Identity and Diversity" in Michele GRAZIADEI and Mauro BUSSANI (eds.), Human Diversity and the Law, Paris, Harmattan, 2005, p. 43; Roderick A. MACDONALD, "Recognizing and Legitimating Aboriginal Justice: Implications for a Reconstruction of Non-Aboriginal Legal Systems in Canada" in ROYAL COMMISSION ON ABORIGINAL PEOPLES, Aboriginal Peoples and the Justice System, Ottawa, Royal Commission on Aboriginal Peoples, 1992, p. 232;

(d) in relation to international trading regimes: Roderick $A$. MACDONALD, "Metaphors of Multiplicity: Civil Society, Regimes and Legal Pluralism", (1998) 15 Ariz. J. Int'1 \& Comp. L. 69; Roderick A. MACDONALD, "Three Metaphors of Norm Migration in International Context", (2009) 34 Brooklyn J. of Int'l L. 603; and

(e) with respect to human rights: Roderick A. MACDONALD, "Pluralistic Human Rights? Universal Human Wrongs?" in R. PROVOST and C. SHEPPARD (eds.), Dialogues on Human Rights and Legal Pluralism, Springer, forthcoming in 2012. For more examples of works from some of these categories, see MACDONALD, "Here, There... and Everywhere: Theorizing Legal Pluralism; Theorizing Jacques Vanderlinden", above, II.D, at pages 382-383.

\section{Course Content}

The facts of the financing example that we rely on in this syllabus were borrowed from Roderick A. Macdonald and Jason McLean's analysis of its possibilities in the transsystemic context in "No Toilets in Park", above, II.D. That article presents another example from the transsystemic curricular model that is instructive for conceptualizing our approach to implicit comparative law. The example - an introductory survey course about the foundations of Canadian law - is a key site for cautioning students against the perils of reifying the transsystemic idea, essentialism and effacing the personal in understanding legal concepts. A "Foundations" course in a non-reified transsystemic curriculum would focus on contingency and agency in examining how legal subjects actively 
imagine and engage with multiple legal orders. Furthermore, for a discussion of how abandoning the default criteria for defining cognates and agnates in the comparative law analysis and how the emergent factors play out in the context of transnational commercial law reform, see Roderick A. MACDONALD, "Article 9 Norm Entrepreneurship" (2006) 43 Can. Bus. L.J. 240 and Roderick A. MACDONALD, "Three Metaphors of International Norm Migration", above.

\section{Assessments \& Feedback}

The language and registers of law and legal inquiry are simultaneously oft-ignored as inherent and oft-criticized as political. Several accounts impel us to challenge the linguistic and planar orthodoxies of legal study: Roderick A. MACDONALD, "Legal Bilingualism", (1997) 42 McGill L.J. 119; Roderick A. MACDONALD and Clarisse KEHLER SIEBERT, "Orchestrating Legal Multilingualism: 12 Études" in J.C. GÉMAR and N. KAISIRER (eds.), Jurilinguistique: entre langues et droits, Montreal, Éditions Thémis, 2005, p. 377; Roderick A. MACDONALD, "Office Politics", (1990) 40 U.T.L.J. 419; Roderick A. MACDONALD and Jonathan WIDELL, "Office Politics (Again)!", (2005) 20 C.J.L.S. 1; Roderick A. MACDONALD, "Custom made - For a Non-Chirographic Critical Legal Pluralism", above, II.D.

Challenging orthodoxy in the classroom entails an appropriate approach to facilitation, evaluation and communication between course participants. Our approach to assessment and feedback is concerned, first and foremost, with learning and learners. For a discussion of the distinction between summative and formative evaluation and the methods and practices of formative evaluation and feedback, see: Phil RACE, "The Art of Assessing", (1995) 4 New Academic; Graham MOWL, "Innovative Assessment", online: <http://www.city.londonmet.ac.uk/deliberations/assessment/mo wl_fr.html>; Barbara GROSS DAVIS, "Grading Practices" in Barbara GROSS DAVID, Tools for Teaching, San Francisco, Jossey-Bass Publishers, 1993; Gerald F. HESS and Steven FRIEDLAND, Techniques for Teaching Law, Durham, NC, Carolina University Press, 1999. 